\title{
Human Resource Management, Total Quality Management and Competitive Advantages: Evidence from Pakistani Banking Industry
}

\author{
Syed Waqar Ahmed \\ Karachi University Business School, University of Karachi, Pakistan \\ E-mail: syedwaqarahmed4@icloud.com \\ Danish Ahmed Siddiqui \\ Karachi University Business School, University of Karachi, Pakistan \\ E-mail: daanish79@hotmail.com
}

Received: February 6, 2020 Accepted: March 1, 2020 Published: March 3, 2020

doi: 10.5296/hrr.v4i1.16410 URL: https://doi.org/10.5296/hrr.v4i1.16410

\begin{abstract}
This study aimed to investigate the relationship between human resource management (HRM) practices, total quality management (TQM) practices and competitive advantages in banking industry of Pakistan. HRM practices included Recruitment \& Selection, Training \& Development, Performance Appraisal, and Compensation \& Reward. TQM practices consist of Leadership, Continuous Improvement, Customer Satisfaction, Employee Empowerment, and Strategic Planning. And lastly, competitive advantages is represented by Cost Leadership, and Differentiation. We applied (Obeidat, Yousef, Tawalbeh, \& Masa'deh, 2018) model to banking sector of Pakistan. An Adopted questionnaire was designed and distributed over a sample of 300 employees. The research hypotheses were tested by using structured equation modeling. The result shows that Compensation \& Reward positively and significantly affect all TQM practices as well as cost leadership. Similarly, Performance Appraisal also produce a significant positive impact on Strategic Planning, and Leadership dimensions of TQM, Hoverer, negatively affect cost leadership. Recruitment \& Selection positively affect cost leadership. Strategic planning an importance factor, significantly affect both competitive advantage factors. Interestingly, Training \& Development have a significant but negative effect on TQM factors namely Continuous Improvement, Leadership, and Strategic Planning.
\end{abstract}




\section{MInstitute Mach $^{m}$}

The findings imply that in banking industry, the effect on HRM factors on TQM is not equal, some are even negative, hence should be used diligently with the prospective of both TQM and competitive advantages.

Keywords: Human resource management, Total quality management, Competitive advantages, Banking, Pakistan

\section{Introduction}

\subsection{Background to the Study}

(HR) is an indispensable asset for any association, and satisfactory administration of HR can enable an association to accomplish its objectives and targets (Abdul-Halim, Che-Ha, Geare, \& Ramayah, 2016). A review of the different literature reveals an increasing interest in the impact of HRM practices on the competitive advantages (Albrecht, Bakker, Gruman, Macey, \& Saks, 2015; Budhwar, Chand, \& Katou, 2007). According to (Al-Mansour, 2007) upper hand and Total Quality Management (TQM) has end up being among the best quality procedures that have been applied. Since the presentation of TQM in the mid-1980s, it has contributed massively to the executives practice the world over. Its significance as a wellspring of upper hand can't be overemphasized by firms. Experimental examinations have indicated that the manner in which associations actualize TQM can fundamentally influence the outcomes and business sway, henceforth associations need to take legitimate measure in executing TQM in their associations.

One of the most valued methods to create sustainable aggressive benefit is through successfully implementing Total quality management (TQM) practices and Human resource management (HRM) practices (Usrof \& Elmorsey, 2016). The most vital challenge for plenty companies these days is to stay on the present competitive marketplace via the effect of privatization, liberalization, globalization, competition (Velmurugan \& Akhilesh, 2019). The market environment can become more complex as groups improve competitiveness and the fine of their merchandise and procedures. As this takes vicinity, businesses can address the ones problems by the use of HRM and TQM as new techniques to answer efficiently to the adjustments in such an environment (Aragon-Sanchez \& Nevers Esteban-Lloret, 2010)

Enhancing the competitiveness of an organization is associated with the TQM and HRM practices. Many researchers have discovered TQM to have an impact on competitiveness using amazing practices for constantly making enhancements to meet the want of purchaser's and consumer and to increase an organization's competitive advantage. According to (Jiménez-Jiménez \& Martínez-Costa, The performance effect of HRM and TQM: a study in Spanish organizations, 2009), organizations attention on enhancing their aggressive advantage with the useful resource of the usage of TQM as an technique via which they might enhance the outstanding of products, human assets, offerings, techniques, and the environment.

According to modern research, HRM practices have the following objectives; facilitate employee involvement, offer guide for continual enterprise improvement, and systematically dispose of waste at the identical time as improving each product and service incredible by using focusing on persistent improvement (Marín García, Medina López, \& Alfalla Luque, 2012). Human resource management practices can significantly have an effect on total quality 
management practices and can also have a massive impact on each employee and patron pride (Yang, 2006). HRM may be defined as a feature approach to accomplishing aggressive benefit (Gandhi, 2014). This may be achieved via a business enterprise's capability to convert distinctive property collectively with economic capital, equipment, strategies and materials into output along with services or products ( (Pankaj, 2012). It also can be completed thru the regulations and practices for coping with people which is probably included with strategic goals and goals (Tamer \& Darwish, 2009).

Banking establishments in Pakistan are located beneath pressure to manipulate competition, globalization, fluctuation within the market, and developing client demand. Accordingly this place must focus on normal performance competitive gain and excessive quality customer support for you to live on in a globally competitive market ( (Al-dalahmeh, Khalaf, \& Obeidat, 2018; Masa'deh, Alrowwad, Alkhalafat, Obeidat, \& Abualoush, 2018). The call for banking services has multiplied rapidly during the last decade due to the changes in way of life and the dwelling requirements of human beings. In addition, this name for has been masses brought approximately via the globalization of commercial agency operations thru all industries alongside the hard paintings, capital and resource flexibility which may be related to the industries (Todeva \& John, 2001; Abualoush, Bataineh, \& Alrowwad, 2018a; Abualoush, Obeidat, Tarhini, Masa'deh, \& Al-Badi, 2018b)

\subsection{Problem Statement}

Businesses become successful because they possess some advantage relative to their competitors (Pearce \& Robinson, 2007). The world is encountering enormous changes as for innovation, improvement, hierarchical practices, advertise structures and government arrangements (Collins \& Smith, 2006; Lall \& Teubal, 1998; Malik \& Kotabe, 2009). All fields of creation are progressively serious, and organizations face extraordinary challenge with rival organizations in their industry (Coad \& Teruel, 2013). These days, an organization will fail and keep up its situation in the market in the event that it doesn't execute key arranging and asset streamlining (Ahlvik, Smale, \& Sumelius, 2016)

The market environment can become more complex as companies improve competitiveness and the quality of their products and processes. As this takes place, companies can tackle these issues by using HRM and TQM as new approaches to respond effectively to the changes in such an environment (Aragon-Sanchez \& Nevers Esteban-Lloret, 2010). Enhancing the competitiveness of an organization is related to the total quality management, and human resource management practices. Many studies have found TQM to have an impact on competitiveness using quality practices for continually making improvements to meet the need of customer's and to increase a company's competitive advantage. According to (Jiménez-Jiménez \& Martínez-Costa, The performance effect of HRM and TQM: A study in Spanish organization, 2009), organizations focus on improving their competitive advantage by using TQM as an approach through which they can enhance the quality of products, human resources, services, processes, and the environment.

\subsection{Gap Analysis}

(Elrehail et al., 2019) Analyzed impact of human resource management practices on achieving competitive advantage in Northern Cyprus hotel industry. The findings revealed 
that HR practices had a significant effect on competitive advantage. (Addae-Korankye) Also found that found out that when properly implemented, TQM will be a source of sustained competitive advantage. However, finding were based on interviews, hence results can't be quantified hence lacks generalization. (Obeidat et al., 2018) Analyzed investigate the relationship between human resource management (HRM) practices, total quality management (TQM) practices and competitive advantages in Telecommunication organizations in Jordan. It was also concluded that there is a relationship between total quality management practices and competitive advantage.

In context of Pakistan, (Adil, 2015) investigated impact of eight strategic human resource management practices on the four competitive priorities (i.e., cost, quality, delivery and flexibility) of the manufacturing performance in Karachi. The results of the structural model show that all of the eight strategic HRM practices collectively demonstrate a very good model fit between the theory and the sample drawn however, both performance appraisal and employment security have been found statistically significant to predict these four priorities in isolation too. (ul Hassan, Mukhtar, Qureshi, \& Sharif, 2012) Also examined the association between total quality management (TQM) practices and performance, i.e. quality, business, and organizational performance in manufacturing industry of Pakistan. This study supports the hypothesis that TQM practices positively impact the performance.

Most of the above-mentioned studies are country specific, mostly done in developed region. Moreover, they haven't covered financial sector. Moreover, studies conducted on Pakistan, only included limited variables. Especially TQM dimensions like Leadership, Continuous Improvement, Customer Satisfaction, Employee Empowerment, and Strategic Planning, were not discussed. Above all, the banking sector, which is arguably the largest service sectors in Pakistan and leading provider of jobs was not focused.

\subsection{Research Objectives}

This study aimed to investigate the relationship between human resource management (HRM) practices, total quality management (TQM) practices and competitive advantages in banking industry of Pakistan. HRM practices included Recruitment \& Selection, Training \& Development, Performance Appraisal, and Compensation \& Reward. TQM practices consist of Leadership, Continuous Improvement, Customer Satisfaction, Employee Empowerment, and Strategic Planning. And lastly, competitive advantages is represented by Cost Leadership, and Differentiation. We applied (Obeidat, Yousef, Tawalbeh, \& Masa'deh, 2018) model to banking sector of Pakistan.

\subsection{Research Question}

1). How human resource management practices effect competitive advantage in banking sector of Pakistan?

2). What is the impact of total quality management practices on competitive advantage in banking sector of Pakistan?

3). Do human resource management practices and total quality management effect competitive advantage in banking sector of Pakistan? 


\subsection{Significance}

This study will add to existing knowledge on competitive advantage enjoyed by Commercial Banks in a developing country like Pakistan and the Human resource and total quality management practices that influence the competitive advantages. Scholars, academicians and researchers can use the study as a reference point in evaluating these factors influence on competitive advantage of Commercial Banks in Pakistan or when looking at competitive advantage in general.

This study seeks to contribute further to this wealth of knowledge and find out other business practices that can be adopted to gain competitive advantage. Commercial banks and other organizations shall be able to borrow from these other factors while formulating their strategies. There are many routes to competitive advantage. The route a firm adopts would be based on its position within the industry. While formulating its policy, it is important for the firm to understand where it is so as to adopt the best strategy in a bid to achieve its competitive advantage. From this study, the commercial banks will be able to identify human resource and total quality management effect on competitive advantages that there are and given their resources and position within the environment they can be able to have the best mix of strategies to give them an edge over their competitors.

\section{Theoretical Framework}

\subsection{Human Resource Practices}

(Li \& Wu, 2008) Examined how framework excellence can be improved through the administration framework and HRM practices. Since most assistance businesses include collaboration among work force and clients in offering types of assistance, the improvement of HRM practices through preparing and the upkeep of staff work frame of mind and administration capacity is all the more exceptionally respected. Their examination uncovers that TQM in the administration business focuses on a sound plan at the framework level, and TQM is at its best when coordinated with structures in HR practices. This outcomes in better employment frame of mind and upgrades in administration capacity, which thus mean phenomenal assistance quality, progressively fulfilled clients, and an improved association execution.

(Abu-Doleh, 2012) Inspected a few key highlights in particular training and development, worker profession improvement, and recruiting \& selection which seem to have the best impact on the usage of TQM practices. As indicated by this exploration, HRM practices and TQM practices significantly affect organizational quality execution. (Cantarello, Filippini, \& Nosella, 2012) Conducted an experiential study to investigate the relationship between skill-developing HRM practices and quality performance. They find that the expertise creating HRM practices planned for improving the communications among all representatives and creating perform various tasks information could improve workers' capacity to build up an increasingly complete and multifaceted thought of the item by mulling over various needs. (Hataani \& Mahrani, 2013) Showed how TQM significantly enhances the HRM practices. In testing the hypothesis their outcome shows that TQM practices have positive and critical effect on HRM practices. This clarification for this is usage of TQM (at the stature as per the possibilities of businesses) bolsters a decent administration, a minimal group, worker 
commitment and the opening of data frameworks. In addition, (Dubey, Singh, \& Ali, 2015) found that HR mediates completely through leadership and quality culture practices for successful TQM implementation that enhances firm performance. (Huselid, 1995) Has distinguished the connection between HRM practices and turnover, efficiency and money related execution (Delaney \& Huselid, 1996) Contended HRM practices, especially determination and preparing, are related with apparent firm execution in benefit and not-for-profit associations. Similar results are reported by (Gooderham, Ringdal, \& Parry, 2006, September) who found a positive impact of HRM practices on firm performance.

In a study in Greece (Katou \& Budhwar, 2006) found that HRM practices of staffing, preparing and advancement, inclusion of representatives, motivators, and security and wellbeing have positive association with firms' exhibition. In an investigation in Taiwanese high innovation firms (Pao-Long \& Wei-Ling, 2002) set up that HRM practices of workforce arranging, preparing and improvement, advantages, cooperation, and execution examination essentially influenced efficiency. In another examination (Singh, 2003) found that vital utilization of HRM practices emphatically influence execution of associations in India. In Korea (Bae \& Lawler, 2000) concluded that HRM practices significantly affect organizational performance (Lee \& Lee, 2007, November) set up that workforce arranging, cooperation, preparing and advancement, pay and motivating forces, execution examination, and representatives' security are significant HRM measurements that influence profitability, item quality, and business execution. It is contended that HRM practices upgrade representatives' competency and inspiration that influence hierarchical execution (Harel \& Tzafrir, 1996) contended that HRM practices based on quality hiring, development, and retention boosts firms' capability. Researchers (Chiu, Luk, \& Tang, 2002; Terpstra \& Rozell, 1993) have established that HRM practices of extensive recruitment and selection, training and development, and compensation systems have positive association with firms' performance.

(Rondeau \& Wagar, 2001) Examined the co-relation between HRM practices, workplace climate \& perceptions of organizational performance, in a large sample of Canadian nursing homes. The investigation found that nursing homes, which had actualized increasingly 'dynamic' HRM practices, had a general inclination to perform better on various esteemed authoritative results (Budhwar, Chand, \& Katou, 2007), conducted a study to investigate if some characteristics of hotels affect organizational performance in the hotel industry in India $\&$ to examine if some HRM systems affect organizational performance. Their investigation uncovered that lodging execution is emphatically connected with inn classification, kind of inn and inn execution is legitimately identified with HRM frameworks of enlistment and choice, labor arranging, work configuration, preparing and advancement, quality circle and pay framework (Joseph \& Dai, 2009), in their studies found that there is a direct relation between HRM practices \& organizational performance that alignment of HRM is also a driver for organization's performance.

The analysis carried out by (Nayyab, Hamid, Naseer, \& Iqbal, 2011)), revealed HRM practices contribute to the enhanced banks performance. Additionally, the outcome showed that HRM practices like preparing, representative interest in basic leadership were directly corresponding to in general execution of the bank. Further (Osman, Ho, \& Galang, 2011), 
reported in his studies that the effectiveness of implementing HRM practices in an organization has a significant impact towards its performance. The discoveries likewise show that HRM practices legitimately influence practically half of an organization's exhibition. (Huselid, 1995)

\subsubsection{Recruitment \& Selection}

Recruitment and selection process typically include making work promotion dependent on the activity examination and the expected set of responsibilities of an empty position; thereafter, the position is, publicized generally to draw in an enormous number of candidates, and afterward the best up-and-comer is distinguished utilizing approved tests and meetings (Adetunji, 2015). Sources of recruitment may be categorized into two categories - internal and external (Aswathappa, 2008). The internal sources of recruitment include present representatives and worker referrals; outer wellsprings of enlistment are proficient affiliations, Newspaper promotions, spontaneous candidates, the executives counseling firms, and the web (Absar, Recruitment \& selection practices in manufacturing firms in Bangladesh, 2012). Some selection processes may comprise of testing methodology while others procedures may underscore meetings and reference checks (Tabassum, 2011). Thus, the selection process contrasts from one association to other, however the procedures are on the whole commonly comparable, which comprise of the accompanying: rounding out application structures, introductory tests, essential meetings, business tests, composed assessments, exhaustive meetings, reference checks, lastly an employment bid (Absar, Recruitment \& selection practices in manufacturing firms in Bangladesh, 2012)

\subsubsection{Training \& Development}

Training is viewed as the most significant factor in the business division because of the way that preparation gives various advantages. Training creates skills, for example, specialized, human, theoretical and administrative for the encouragement of individual and association development (Kulkarni, 2013). According to (Dessler, 2017) there are five steps in training and development process. The initial step includes a testing system to recognize the particular employment execution aptitudes required; this progression assesses the learners' abilities. The subsequent advance is instructional structure, which alludes to how the preparation program content is resolved, chosen, and planned. There might be a third approval step, in which the imperfections are recognized and expelled from the preparation program by introducing it to a little agent open. The fourth step is to execute the program, via preparing the focused on representative gathering. Ultimately, the last fifth step is an assessment, wherein the administration evaluates the program's triumphs or disappointments.

\subsubsection{Performance Appraisal}

(Phin, 2015) Defined performance appraisal as a procedure of assessing the exhibition of representatives in the work environment. It contains both quantitative and subjective parts of representative occupation execution. It is a procedure to convey to a representative and plan to create for development. Moreover, execution examination is additionally seen as the procedure that influence the status of worker, for example, maintenance, end, advancement, move, pay increment or reduction, or induction into a preparation program (Neeraj, 2014). According to (Singh, 2014), performance appraisal is a systematic method for periodically 
evaluating job performance based on the criteria pre-established and organizational goals.

\subsubsection{Compensation \& Reward}

(Mondy, 2010) Stated compensation as a combination of employees' benefits and services provided to employee in return for their service, which positively affects the retaining and motivating employees. Through Werner represented compensation as "packages entail some basic features that tend to make employees satisfy on their job amongst which includes salaries, bonuses, incentives, allowances, promotion, recognition". In addition, (Gopinath \& Shibu, 2016) viewed compensation as a payment got by the employee for its commitment to the association, which is an essential piece of the HR the executives Gateway through the financial and non-fiscal advantages which help in propelling workers and improving the viability of the association. Remuneration has a few advantages, for example, the capacity to accomplish worker fulfillment and representative maintenance and increment execution in the organization (Osibanjo, Adeniji, \& Heirsmac, 2014).

\subsection{Total Quality Management Practices}

(Mwaniki \& Okibo, 2014) Focused on deciding the Effects of complete quality administration on money related execution in the financial part: The discoveries of the examination demonstrated a positive connection between top administration inclusion, procedure and provider relationship and monetary execution.

In their investigation (ul Hassan, Mukhtar, Qureshi, \& Sharif, 2012) analyzed the relationship between quality administration practices and execution, for example quality, business, and hierarchical execution. The quantitative information were acquired through a review from 171 quality directors of Pakistan's assembling industry. This investigation underpins the theory that quality administration frameworks practices decidedly sway the presentation. Quality administration frameworks devices and procedures (Incentive and Recognition System, Process, Monitoring and Control and Continuous Improvement) and Behavioral elements (Fact based-administration, top administration's duty to quality, worker inclusion and client center) add to the fruitful usage of value the board frameworks. The investigation reports that fruitful reception and usage of value the executives frameworks practices brings about improving the presentation of association. The fundamental ramifications of the discoveries for administrators is that with quality administration frameworks works on, fabricating associations are bound to accomplish better execution in consumer loyalty, worker relations, quality and business execution than without quality administration frameworks rehearses.

As per (Irfan, Ijaz, Kee, \& Awan, 2012) in the examination on Improving Operational Performance of Public Hospital in Pakistan utilized a poll with fourteen Quality administration frameworks practices to gauge the effect of Quality administration frameworks rehearses on operational execution of open medical clinic in Pakistan. Auxiliary Equation Modeling (SEM) approach with AMOS 16.0 was utilized to build up a Quality administration frameworks and execution model. An aggregate of 239 polls was remembered for the examination and the outcomes show that chose Quality administration frameworks practices has a critical positive effect on quality administration frameworks usage and furthermore on operational execution as far as expanded adaptability, improved nature of 
administrations, decrease in administration time and successful diagnostics. In analyzing whether quality administration work in the open segment

(Adeoti, 2003) Examined the increases of use of all out quality administration in the administration business with specific reference to the business banks in Nigeria and furthermore to perceive how the utilization of TQM can forestall future dangers of misery in business banks. Three banks were chosen haphazardly, one to speak to every one of the three age banks. The consequences of the examination demonstrated that the quality and amount of representatives utilized decide to an enormous degree the endurance of any bank, additionally that the use of TQM isn't insusceptibility against trouble however a preventive system for trouble.

\subsubsection{Continuous Improvement}

(Caroly, Coutarel, Landry, \& Mary-Cheray, 2010), defined continuous improvement as a procedure that means to control generation costs and improve quality through advance data, physical streams, and items (Chen, Li, \& Shady, 2010), he described continuous improvements as the "continuous identification and elimination of waste". Another explanation for continuous improvement is provided by (Shafeek, 2014), Shafeek call it is an ongoing effort to improve maintenance aimed at maintenance process simplification and reduction or elimination of maintenance process waste. Since the core of strategic planning in any organization is to improve the profitability esteem, improving serious picture of the association, improving generally speaking adequacy, diminishing cost, lessening administrator botches, wiping out waste, and keeping up wellbeing and security models, ceaseless improvement assumes a significant job in since quite a while ago run (Singh \& Singh, 2014).

\subsubsection{Customer Satisfaction}

Consumer loyalty is one of the basic achievement factors in the present serious business condition as it impacts organizations' piece of the overall industry and client maintenance (Ooi, Lin, Tan, \& Chong, 2011). Clients are frequently viewed as the most significant resource of any association; subsequently, the accomplishment of an association relies upon its number of clients (Iakov, 2013). Customer delight was related to people who paid for a products or services and used the products and services (Ling, Yeo, \& Lim, 2016). It is alluding to how an item fulfills clients or how it satisfies their needs and desires (Bitner \& Zeithaml, 2003). (Qi, Zhou, Chen, \& Qu, 2012) Defined customer satisfaction as correlation among desires and the apparent presentation after a particular buy. Consequently, consumer loyalty is accepted a positive determinant of how solid is the connection between the client and the item supplier (Saleh, 2015).

\subsubsection{Employee Empowerment}

Employee empowerment as a strategy that enhance organizational performance; it additionally assists with building up an adaptable association that can be equipped for adjusting to a changing outside condition (Ferit, 2015). When employees experience empowerment and see the impact of their jobs are having on the organization, they identify more with the goals of the organization and as a result are more committed to it (Elloy, 2012). Similarly it has been seen that employee empowerment is imperative to hierarchical ingenuity 
and viability; with the ideal people, work attributes and authoritative condition, worker strengthening can noticeably affect inspiration and execution (Kimolo, 2019). Thus, employee empowerments can also improve productivity, performance and job satisfaction (Greasley et al., 2005).

\subsubsection{Strategic Planning}

In the present, strategic planning for all businesses has gotten completely essential, as there gives off an impression of being remarkable marvel where each part is being faced with significant increments in both vulnerability and rivalry (Vel, Creed, \& Narayan, 2012). A wide range of benefit or non-benefit associations are believed to be engaged in a strategic planning process (Hough, Thompson, Strickland, \& Gamble, 2011). Strategic planning deals with making long-term decision that help organization to respond to changing environments (Volberda, 2010; Suklev \& Debarliev, 2015) Described strategic planning as activities that are geared towards obtaining success and remaining competitive in any sector. An appropriate strategic plan helps organization to change their plans according to market needs; it focuses on the organizational planning process (Brah \& Lim, 2006).

\subsubsection{Leadership}

The topic of leadership has been examined extensively by various scholars, such as (Sharma \& Jain, 2019) who defined leadership as "a procedure by which a person influences other to accomplish an objective and directs the organization in a way that makes it more cohesive and coherent". Similarly, (Northouse, 2010) viewed leadership as a process by which a person influences other to achieve common goal. (Sălăgean, 2014)1also provided a definition for leadership in which he considers the most significant asset that holds without which every other asset, and it figures out how to adapt to changes. (Helmrich, 2015) Also described leaders as people who know how to realize objectives and encourage people along the way.

\subsection{Competitive Advantage}

Some of the factors that influence competitive advantage are discussed below.

Superior resources are the tangible requirements for advantage that enable a firm to exercise its skills. Superior resources include the number of sales people in a market, the expenditure on advertising and sales promotion, distribution coverage, expenditure on R\&D. scale of and type of production facilities, financial resources, brand equity and knowledge (David Jobber, 2007). Employees are a key resource to any organization. Low turnover rate is likely to increase the sustainable competitive advantage of an organization. According to (Torrington, Hall, \& Taylor, 2005), training opportunities enhance commitment to an employer on the part of individual employees, making them less likely to leave voluntarily than they would if no training were offered.

The second step in resource and capability analysis is designed to ascertain which of a company's resources and capabilities are competitively valuable and to what extent they can support a company's quest for a sustainable competitive advantage over market rivals. This involves probing the caliber of a firm's competitive assets relative to those of its competitors. When a company has competitive assets that are central to its strategy and superior to those of rival firms, it has a competitive advantage over other firms. If this advantage proves durable despite the best efforts of competitors to overcome it, then the company is said to 
have sustainable competitive advantage.

\subsubsection{Cost Leadership}

The cost leadership strategy, a procedure that are taken to create products or administrations with features that are qualified to customers to the detriment, for the most part lower than that of contenders (Ireland, Hokisson, \& Hitt, 2011). This technique depends on a company's capacity to give an item or administration at a lower cost than its adversaries (Abd Aziz \& Samad, 2016). Hence, firms that seek after a cost initiative methodology should consistently benchmark themselves against other opponent firms so as to gauge their relative expense and benefit position in the commercial center (Wen-Cheng, Chien-Hung, \& Ying-Chien, 2011). Organizations can follow cost leadership strategy, at the point when the market is made out of many value touchy purchasers, likewise when the clients don't give a lot of significance for brand, value affectability and purchasers have huge bartering power (Abdullah, Mohamed, Othman, \& Uli, 2009).

The link between technological change and competitive advantage suggests a number of tests for a desirable direction of technological change. Technological change by a firm will lead to sustainable competitive advantage under the following circumstances: the technological change itself lowers cost or enhances differentiation and the firm's technological lead is sustainable. A technological change enhances competitive advantage if it leads to lower cost or differentiation and can be protected from limitation. Technological lead is sustainable if technological change shifts cost or uniqueness drivers in favor of a firm. Changing the technology of a value activity, or changing the product in ways that affect the value activity, can influence the drivers to cost or uniqueness in that activity. Even if the technological change is imitated, therefore it will lead to a competitive advantage for a firm if it skews drivers in the firm's favor (Porter, 1998). Product differentiation refers to the uniqueness of the product that customer's value. Its two underlying sources are brand identification and customer loyalty (Peng, 2009).

\subsubsection{Differentiation}

Differentiation Advantage incorporates making items or administrations that are not quite the same as - and more alluring than those of different contenders. This relies upon the specific idea of both the business and the items and administrations themselves (Rahman, 2011). This point is note by (Othman, 2016), who expresses that separation systems depend on offering purchasers something one of a kind or diverse that makes the company's item or administration unmistakable from that of contenders. Clients are likely prepared to address a top-notch cost for an item that is particular in a significant manner, for example, having a superior help, an unrivaled quality or extraordinary intrigue. Differentiation usually arises from one or more activities in the value chain that create a unique value important to buyers (Pearce \& Robinson, 2007). It requires that the business have sustainable advantages that allow it to provide buyers with something uniquely valuable to them. A successful differentiation strategy allows the business to provide a product or service of perceived higher value to buyers at a "differentiation cost" below the "value premium" to the buyers. In other words, the buyer feels the additional cost to buy the product or service is well below what the product or service is worth compared with other available alternatives (Keegan \& Green, 2008). 
2.3.3 Human Resource Management Practices and Competitive Advantage

HRM practices factors and functions performance appraisal, compensation, selection practices, employment security, job descriptions, career opportunities, and training and development practices can be grouped as a way to impart to the representatives in regards to the particular aptitudes and practices important to make and support an upper hand (Adil, 2015). On the off chance that very much oversaw, HR can possibly be a wellspring of practical upper hand and affect principal goals, for example, quality, benefits and consumer loyalty (Absar et al., 2012). In addition, if HRM practices are used for improving competencies that are company specific and for creatinine of organizational knowledge, there is a possibility that competitive advantage can be sustained (Lazim, Azizanm, \& Sorooshianm, 2015). According to (Mark, 2011), HRM practices of an association can be a significant wellspring of upper hand through cost administration and item separation. The upper hand acknowledged through HRM practices can be more reasonable than that accomplished by different methods.

H0.1: There is no statistically significant effect of HRM practices on competitive advantage.

Sub Hypothesis:

H0.1.1: There is no statistically significant effect of recruitment and selection on Cost Leadership

H0.1.2: There is no statistically significant effect of performance appraisals on Cost Leadership

H0.1.3: There is no statistically significant effect of training, development on Cost Leadership

H0.1.4: There is no statistically significant effect of compensation, reward on Cost Leadership

H0.1.5: There is no statistically significant effect of recruitment and selection on Differentiation

H0.1.6: There is no statistically significant effect of performance appraisals on Differentiation H0.1.7: There is no statistically significant effect of training, development on Differentiation H0.1.8: There is no statistically significant effect of compensation, reward on Differentiation

\subsubsection{Total Quality Management Practices and Competitive Advantage}

According to (Herzallah, Gutiérrez-gutiérrez, \& Rosas, 2014), TQM could achieve competitive advantage because it apparently brings about an improved monetary exhibition, more noteworthy consumer loyalty, a quicker reaction to serious condition and improved item quality. As referenced, TQM parts move towards improved a company's improved presentation, for example, more prominent degrees of consumer loyalty, process improvement, and business execution. This thusly creates upper hand for firms (Jung, 2009). In addition, TQM practices enhanced competitive advantage. The objective of value the board is to diminish costs and improve consumer loyalty. These thoughts fit with the market-based vision of upper hand emerging from a better cost structure or being capable than separate items such that upgrades an incentive for clients; likewise, the decreased modify and investment funds that rise up out of improving item quality can help bring down a 
company's cost structure, and delivering items that better fulfill the necessities of clients makes, the plausibility for differentiation (Friend, 2015). Hence, based on above discussion, following hypothesis are proposed.

H0.2: There is no statistically significant effect of TQM practices on competitive advantage.

Sub Hypothesis:

H0.2.1: There is no statistically significant effect of leadership on Cost Leadership

H0.2.2: There is no statistically significant effect of continuous improvement on Cost Leadership

H0.2.3: There is no statistically significant effect of customer satisfaction on Cost Leadership

H0.2.4: There is no statistically significant effect of employee empowerment on Cost Leadership

H0.2.5: There is no statistically significant effect of strategic Planning on Cost Leadership

H0.2.6: There is no statistically significant effect of leadership on Differentiation

H0.2.7: There is no statistically significant effect of continuous improvement on Differentiation

H0.2.8: There is no statistically significant effect of customer satisfaction on Differentiation

H0.2.9: There is no statistically significant effect of employee empowerment on Differentiation

H0.2.10: There is no statistically significant effect of strategic Planning on Differentiation

2.3.5 Total Quality Management Practices and Human Resource Management Practices

In actualizing all out quality administration forms in an association, the human resource department assumes a significant job in a few territories. Such regions are creating and conveying the TQM vision, setting up the authoritative subtleties for the usage of TQM strategies, and offering important help to keep up the eagerness about TQM (Izvercian, Radu, Ivascu, \& Ardelean, 2014). (Kumar, 2012) Stated that TQM impacts the strategy process at all levels. In terms of HRM, TQM has an impact on an organization's culture as well as its work organization, staffing and planning, performance appraisal and compensation, and training and development policies and practices. Consequently following hypothesis are developed.

H0.3: There is no statistically significant effect of HRM practices on TQM practices.

Sub Hypothesis:

H0.3.1: There is no statistically significant effect of recruitment and selection on Leadership.

H0.3.2: There is no statistically significant effect of performance appraisals on Leadership

H0.3.3: There is no statistically significant effect of training and development on Leadership.

H0.3.4: There is no statistically significant effect of compensation and reward on Leadership

H0.3.5: There is no statistically significant effect of R\&S on Continuous Improvement

H0.3.6: There is no statistically significant effect of performance appraisals on Continuous Improvement

$\mathrm{H} 0.3 .7$ : There is no statistically significant effect of T\&D on Continuous Improvement 


\section{Macrothink}

Human Resource Research

ISSN 1948-5441 2020, Vol. 4, No. 1

H0.3.8: There is no statistically significant effect of comp. and reward on Continuous Improvement

H0.3.9: There is no statistically significant effect of $R \& S$ on Customer Satisfaction

H0.3.10: There is no statistically significant effect of performance appraisals on Customer Satisfaction

H0.3.11: There is no statistically significant effect of T\&D on Customer Satisfaction

H0.3.12: There is no statistically significant effect of comp. and reward on Customer Satisfaction

H0.3.13: There is no statistically significant effect of R\&S on Employee Empowerment

H0.3.14: There is no statistically significant effect of performance appraisals on Employee Empowerment

H0.3.15: There is no statistically significant effect of T\&D on Employee Empowerment

H0.3.16: There is no statistically significant effect of comp. and reward on Employee Empowerment

H0.3.17: There is no statistically significant effect of R\&S on Strategic Planning

H0.3.18: There is no statistically significant effect of performance appraisals on Strategic Planning

H0.3.19: There is no statistically significant effect of training and development on Strategic Planning

H0.3.20: There is no statistically significant effect of compensation and reward on Strategic Planning

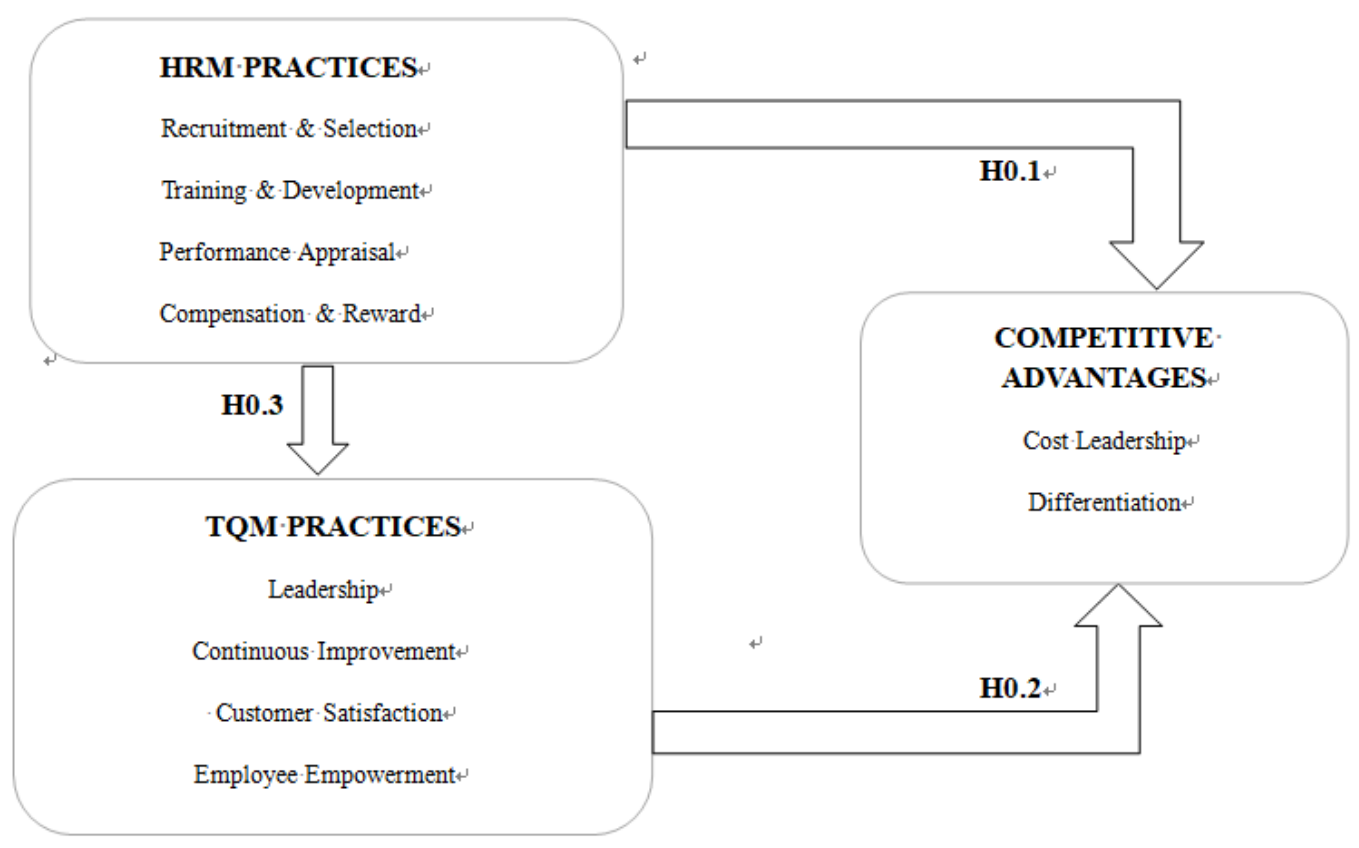

Figure 1. The proposed research framework 


\section{Research Method}

The target population for this survey was banking sector staff in Pakistan, who are working at different level. Participation was on a voluntary basis and no financial incentive was offered. This study employed a convenience sampling method as it allows the researchers to select the sample subjects from the targeted population based on who are willing and easily accessible to be recruited in the research. It is also the least expensive, least time-consuming among all other techniques. A total of 300 self-administered questionnaires were distributed to the employees in different banks, the number of returned questionnaires were 204 indicating a $68 \%$ response rate.

The questionnaire questions are adopted from an established instrument previously used in other researches for measuring each HRM practices, TQM practices and competitive advantage. The questionnaire consists of 66 questions. More specifically, the questions measure the HRM practices, TQM practices and Competitive Advantages were adopted from the study of (Obeidat, Yousef, Tawalbeh, \& Masa'deh, The Relationship between Human Resource Management (HRM) Practices, Total Quality Management (TQM) Practices and Competitive Advantages, 2018). Moreover, HRM practices is measured using (recruitment and selection, performance appraisals, training \& development and compensation $\&$ reward), TQM practices is measured using (leadership, continuous improvement, customer satisfaction, employee empowerment, and strategic planning) and Competitive Advantage is measured using (cost leadership and differentiation advantage). All the items under each variable construct were gauge using 5-point Likert scale ranging from 1- strongly disagrees to 5-strongly agree.

A PLS Smart methodology was employed to test the hypotheses and descriptive statistics was used to explore data characteristics. PLS Smart allows for the test, in the same analysis, of factor analysis and hypotheses. Thus, PLS Smart techniques also provide fuller information about the extent to which the research model is supported by the data beyond regression techniques. The result is a more rigorous analysis of the proposed research model and, very often, a better methodological assessment tool.

\subsection{Demographic Analysis}

Table 1. Respondent's profile

\begin{tabular}{llll}
\hline VARIABLE & CATEGORY & FREQUENCY & PERCENTAGE \\
\hline \multirow{2}{*}{ GENDER } & MALE & 150 & $73.52 \%$ \\
& FEMALE & 54 & $26.48 \%$ \\
20-24 YEARS & 50 & $24.51 \%$ \\
25-29 YEARS & 73 & $35.78 \%$ \\
30-34 YEARS & 33 & $16.18 \%$ \\
\multirow{2}{*}{ 3GE } & 35-39 YEARS & 25 & $12.25 \%$ \\
& 40-44 YEARS & 13 & $6.37 \%$ \\
& 45-49 YEARS & 4 & $1.96 \%$ \\
& 50-54 YEARS & 4 & $1.96 \%$ \\
& $44-59$ YEARS & 2 & $0.98 \%$ \\
\hline
\end{tabular}




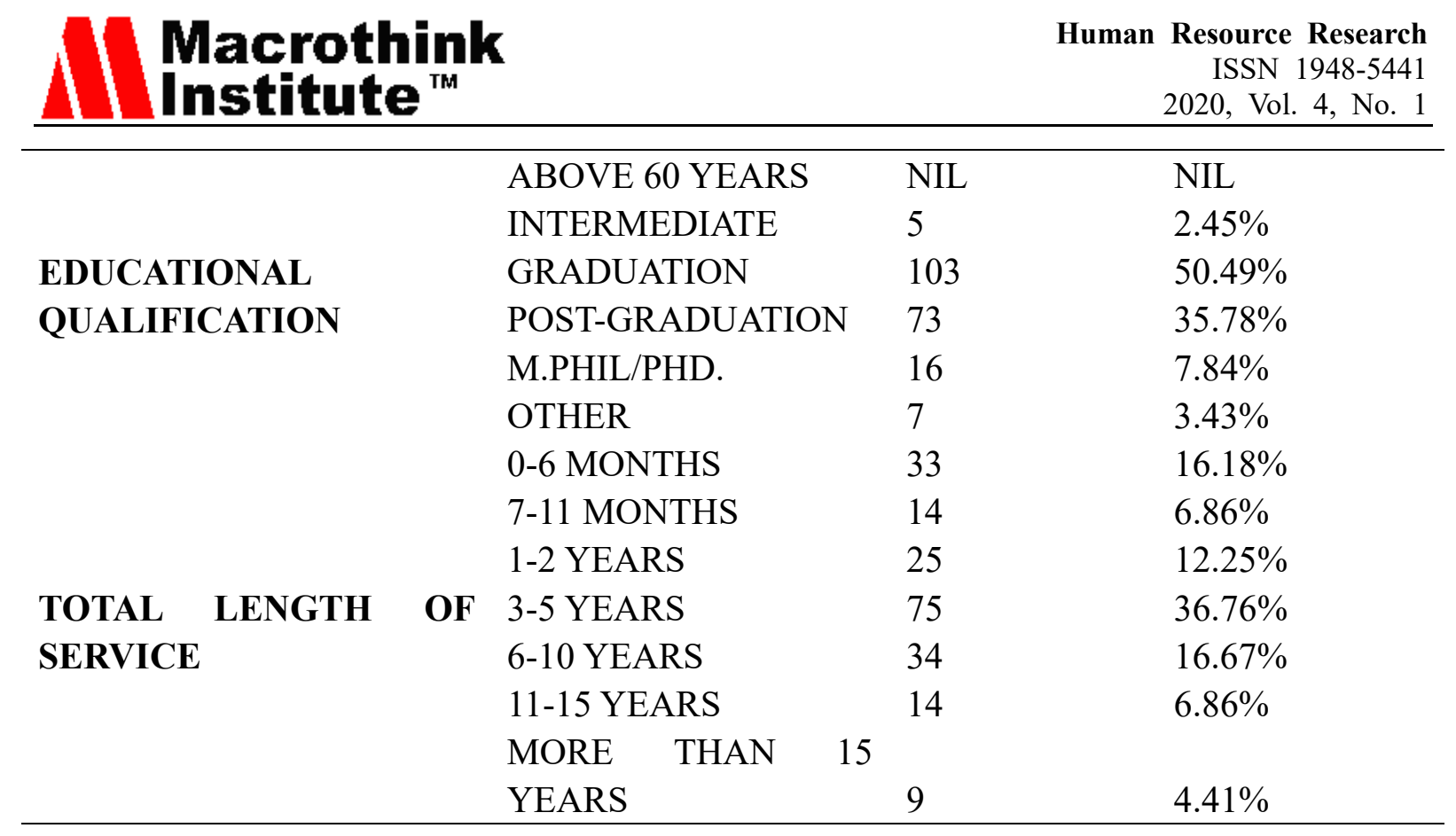

In regard to the gender, the majority of the samples were males $(73.52 \%)$ and females represent $(26.48 \%)$ of the sample. The respondents were mostly aged between 20 to 30 years, which were $(60.29 \%)$ of the total respondents. For the qualification the majority $(50.49 \%)$ of employee has a bachelor degree, with small percentage for Ph.D. level represent $(7.84 \%)$ and master degree represent (35.78\%).The experience of employee as shown in Table (1), $(36.76 \%)$ have an experience up to 5 years while (13.53\%) have an experience of 6 to 10 years and finally $(11.27 \%)$ have an experience of above ten years.

The result shows that the majority of respondents were young and majority of them hold a bachelor and master degree. This may suggest that these groups highly known importance of HRM practices and TQM practices in improving work purpose. From the result, it can also be seen that number of male are more than female which may imply that men have more time to apply HRM practices and TQM practices. Finally, according to the findings people with less than 5 years of experience gives effective competitive advantage to organization other than senior employees. 


\section{Ml Macrothink}

\subsection{Descriptive Statistics}

Table 2. Descriptive statistics

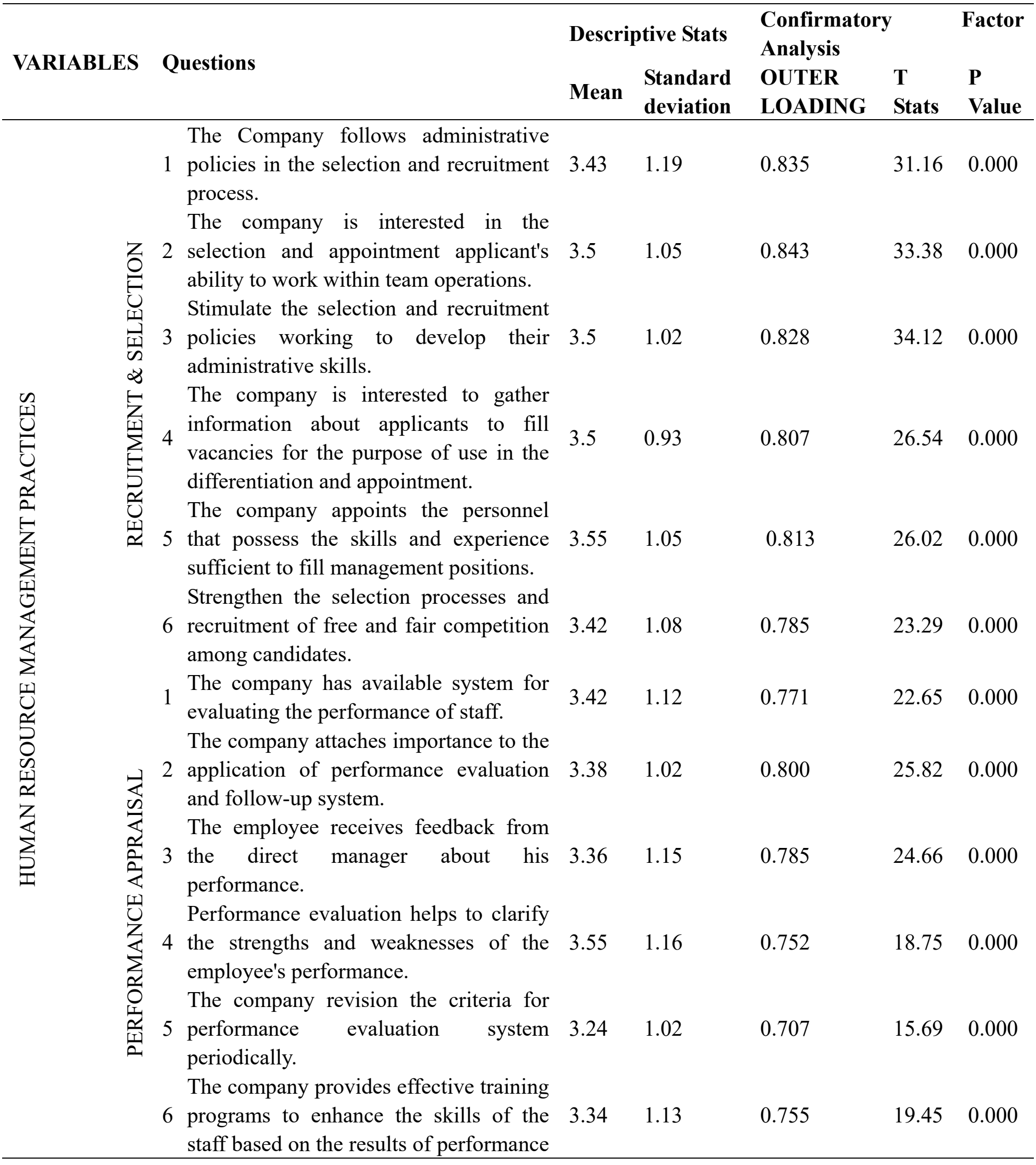


evaluation.

7

Evaluation system applied in the

7 company provides an opportunity for communication between the employee $3.50 \quad 1.06$

0.690

$14.81 \quad 0.000$

and the manager.

The company provision of appropriate

1 training for staff as required by the nature of the work of all of them.

The company through regular plan and a

2 variety of tools identify of training needs.

Characterized by the training programs

3 offered to employees in the company's realistic and relevant document needs.

The company relies regular training

4 programs for the development of the

4 performance of the new workers in the

$3.52 \quad 1.10$

0.789

$23.63 \quad 0.000$

skills necessary for them.

In your Organization, learning is

5 planned and purposeful rather than accidental.

Training programs provide the

6 opportunity to exchange information,

knowledge and experiences among

$3.72 \quad 1.08$

0.772

$22.35 \quad 0.000$

participants.

The company revision of the

1 compensation and reward system based on the company's competitive 3.50 1.06

0.806

$25.40 \quad 0.000$ environment.

Senior management of the company

2 stimulate the staff through the

2 application of compensation and reward system.

Compensation and reward processes for

3 employees based on the principles and criteria evaluation.

Appropriate compensation and reward

4 offered by the company with the staff's expectations.

Compensation and reward system

5 contribute to the company encouraged employees to achieve the company encouraged employees to achieve the 3.48

$\begin{array}{lllll}3.56 & 0.98 & 0.745 & 17.39 & 0.000\end{array}$

$\begin{array}{lllll}3.38 & 1.18 & 0.811 & 33.20 & 0.000\end{array}$

$\begin{array}{lllll}3.41 & 1.08 & 0.762 & 24.42 & 0.000\end{array}$ $\begin{array}{llll}1.14 & 0.751 & 18.32 & 0.000\end{array}$ 
company's goals.

Management believes that quality is the

1 way and philosophy in the conduct of its business.

Leadership is working to spread the

2 culture of quality in all departments and administrative levels.

3 The company is working hard to be the company's outstanding services.

The company has clear plan about the

4 quality of certain specific goals and committed management application.

Leaders seek to build a reputation

5 among customers, based on the quality and workmanship.

Adopts senior management standards of

6 quality in the work encourages outstanding performance among

3.69

0.97

1.04

0.781

$17.96 \quad 0.000$

employees Environment.

The company is constantly working to

1 get rid of activities that do not add value to the service.

2 Management relies on advanced technological programs.

3 its performance compared to

3 competitors in the development of plans to improve performance.

4 The company engage employee in the development plans to achieve quality. The company monitor the extent of

5 improvement in the quality of services provided by the company and compare it to previous years.

6 There is a continuous improvement in working conditions and conditions.

There is a clear and specific strategy

7 that includes improving the quality of $3.62 \quad 1.00$ work plans.

The company focuses on achieving of their requirements. 
2 The company responds quickly to meet the wishes of customers.

The company's management realizes

3 study the market to know the needs and desires of consumers.

The company is keen to offer a wide

4 range of products to meet the needs and desires of the largest number of customers.

The company's management is

5 interested in the customers' complaints and suggestions.

6 The company is fully covered for the various needs of the market.

The company management give

1 material or moral rewards to employees for their participation in achieving 3.59

0.98

$3.62 \quad 1.02$

$3.57 \quad 1.08$

0.739

$18.57 \quad 0.000$

$3.58 \quad 1.08$

$3.53 \quad 1.05$

0.738

$20.97 \quad 0.000$

3.46

1.15

0.828

$34.73 \quad 0.000$ outstanding performance.

The company management authorizes

2 for workers the powers to act in emergency situations.

The company management provides

3 freedom for workers to make decisions independently.

The company is interested in the

4 participation of all workers to improve quality and performance.

The company is interested in the

5 participation of all workers to improve quality and performance.

The company management uses

1 scientific methods and advanced technological tools for the purpose of achieving its strategic plan.

The company is seeking to modify its

2 strategic objectives according to the changing needs in a competitive market.

The strategic goals of the company are

3 related to its mission and vision of the future.

The company management aware the

4 concept of strategic planning and the fields.
$3.18 \quad 1.20$

$3.51 \quad 1.04$

1.00

0.753

$21.96 \quad 0.000$

3.36

1.11

0.670

$12.00 \quad 0.000$

3.45

1.08

0.828

$30.47 \quad 0.000$

$3.54 \quad 1.05$

0.769

$21.75 \quad 0.000$

$3.72 \quad 0.97$

0.773

$22.12 \quad 0.000$

$3.71 \quad 1.00$

0.755

$16.16 \quad 0.000$ 


\section{5}

The company set a timetable appropriate to achieve each strategic goal.

$3.63 \quad 1.02$

0.830

$34.06 \quad 0.000$

The company choose appropriate

6 strategies to achieve the most

appropriate to fit internal and external

$3.60 \quad 1.06$

0.844

$36.62 \quad 0.000$ conditions by the present and future.

The company works to achieve a

1 distinctive brand of their services compared to competitors.

The company is working to develop a

rapid and effective distribution channels

for the delivery of its services to 3.69

$3.64 \quad 1.02$

0.839

$38.70 \quad 0.000$

customers better than competitors.

The company is seeking to gain access

3 to new markets are difficult to access by competitors.

4 The company is working to provide new services and benefits from competitors.

The company employs advanced

5 technologies in the provision of services.

The company offers its services in a

6 manner to ensure excellence and uniqueness of all competitors.

1 The company is seeking to get the price advantages of suppliers to reduce costs.

The company is working to control administrative cost.

The company is working to reduce

3 distribution cost and promote as much as possible.

The company employs its potential to

4 meet the needs and specific requirements in the local market the

$28.66 \quad 0.000$

$3.57 \quad 0.98$

0.831

$38.65 \quad 0.000$ lowest possible cost.

The company is working on the optimal

5 utilization of available resources in order to achieve competitiveness at all $3.55 \quad 1.00$

0.777

$19.43 \quad 0.000$ levels.

The company is seeking to enhance the

6 productivity of individuals within the physical capabilities. 
It is observed from the above table that items related to recruitment and selection have mean score in range 3.42 to 3.55 , while the same items deviate in range 1.02 to 1.19 and the general mean value of recruitment and selection is 3.48 . The overall mean value suggest responses are more closely towards "67.6\% Agreement" at five-point Likert Scale. Items related to performance \& appraisal have mean score in range 3.24 to 3.55 , while the same items deviate in range 1.02 to 1.16 and the general mean value of performance $\&$ appraisal is 3.39 . The overall mean values suggest responses are more closely towards " $67.8 \%$ Agreement" at five-point Likert Scale. Items related to training \& development have mean score in range 3.37 to 3.72 , while the same items deviate in range 1.01 to 1.16 and the general mean value of training \& development is 3.48. The overall mean values suggest responses are more closely towards " $69.6 \%$ Agreement" at five-point Likert Scale. Items related to compensation $\&$ reward have mean score in range 3.38 to3.56, while the same items deviate in range 1.01 to 1.16 and the general mean value of compensation \& reward is 3.46 . The overall mean values suggest responses are more closely towards "69.2\% Agreement" at five-point Likert Scale.

The overall mean value of independent variable HRM Practices is 3.45, which suggest that in banking sector respondent employees are agreed and satisfied to have HRM practices. This result in general indicates that banking industry in Pakistan is interested to provide employee with best HRM practices that can improve their competitive advantage.

Items related to leadership have mean score in rang 3.56 to 3.71 , while the same items deviate in range 0.97 to 1.07 and the general mean value of leadership is 3.64. The overall mean values suggest responses are more closely towards "72.8\% Agreement" at five-point Likert Scale. Items related to continuous improvement have mean score in range 3.35 to 3.62, while the same items deviate in range 0.95 to 1.15 and the general mean value of continuous improvement is 3.53 . The overall mean values suggest responses are more closely towards 70.6 "\% Agreement" at five-point Likert Scale. Items related to customer satisfaction have mean score in range 3.53 to 3.62 , while the same items deviate in range 0.98 to 1.08 and the general mean value of suggest customer satisfaction is 3.58 . The overall mean values suggest responses are more closely towards "71.6\% Agreement" at five-point Likert Scale. Items related to employee empowerment have mean score in range 3.18 to 3.49 , while the same items deviate in range 1.0 to 1.20 and the general mean value of employee empowerment is 3.40. The overall mean values suggest responses are more closely towards " $68 \%$ Agreement" at five-point Likert Scale. Items related strategic have mean score in range 3.45 to 3.72, while the same items deviate in range 1.0 to 0.97 and the general mean value of strategic is 3.60 . The overall mean values suggest responses are more closely towards " $72 \%$ Agreement" at five-point Likert Scale.

In general, it appears that the Importance level of TQM practices was high with an overall mean of 3.55. Almost all TQM items have a moderate level of importance which mean that the banking industry in Pakistan are highly focuses service quality, which it help predict future revenue and help to outpace competition.

Items related to cost leadership have mean score in range 3.47 to 3.69 , while the same items deviate in range 0.97 to 1.07 and the general mean value of cost leadership is 3.59 . The 
overall mean values suggest responses are more closely towards " $71.8 \%$ Agreement" at five-point Likert Scale. Items related to differentiation advantage have mean score in range 3.54 to 3.62 , while the same items deviate in range 0.95 to 1.01 and the general mean value of differentiation advantage is 3.57. The overall mean values suggest responses are more closely towards " $71.4 \%$ Agreement" at five-point Likert Scale.

In general, it appears that the Importance level of dependent variable competitive advantages was high with an overall mean of 3.59. It shows that to have success and sustainability in the market, banking sector must have competitive advantages.

It has been also shown in the table that mostly the items related to variables are having loading values more than 0.70 thus it supports strong loading. On the other hand, $T$ values are supported to be more than 1.96 for all items along with $\mathrm{p}$ values $<0.05$. While item no.7 of performance appraisal and item no.5 of employee empowerment have an irrespective values of loading.

\subsection{Structural Equation Modeling}

To test the (hypothesis) examination speculation we have utilized the basic condition model (SEM) while the testing has been experienced Smart PLS programming. In addition, to assess the aberrant and direct impacts of the considerable number of develops the testing was finished. The use of (SEM) structural equation model has been observed to be a foremost procedure that has been used below different regression models and methods (Baron \& Kenny, 1986).It used to assess the auxiliary connection among exogenous and endogenous factors. It incorporates factor investigation and multivariate examination. In addition, the condition of relapse focuses at disclosing each develop to evaluate the circumstances and logical results relationship while the entirety of the components in the causal model could show their circumstances and logical results at specific time. In like manner, utilizing this model guarantees to apply strategy of bootstrapping which has been seen as sensible for both little and enormous example size and doesn't require any sort of circuitous impact (Hayes, 2013)So as to check the all immediate and aberrant impacts, a method has been executed which is known as bootstrapping (Shrout \& Bolger, 2002).

\subsection{Measurement of Outer Model}

The objective of proportion of fit in the estimation model is to learn about the unwavering quality and legitimacy of the instrument and to check its dependability and legitimacy we perform trial of united legitimacy and discriminant legitimacy in programming naming Smart PLS.

\subsection{Composite Reliability}

Reliability implies stability of questionnaire outcomes. It shows inside consistency and repeatability of the review is high. The essential measure for unflinching quality is to keep up a key good ways from shamefulness in look into. Right now, will in general be improved by testing the interest strategy and examination, as is finished using various research and assessment procedures or various scientists. This additionally consolidates the constancy and authenticity of the investigation.

Reliability of the estimation instruments was assessed utilizing composite dependability. All 


\section{Macrothink

the qualities were over the ordinarily utilized edge esteem for example 0.70 . This is the acknowledged unwavering quality worth range. Estimation of unwavering quality should be possible by level of consistency that lies among different factors (Hair, 2010). Below is the table of composite reliability.

As can be shown in Table 3, the results show that the constructs have adequate reliability.

Table 3. Reliability analysis using the approach of Cronbach's Alpha

\begin{tabular}{llll}
\hline Number & Item & Cronbach's Alpha & Mean \\
\hline 1 & Recruitment and Selection & 0.902 & 3.48 \\
2 & Performance Appraisals & 0.910 & 3.39 \\
3 & Training and Development & 0.901 & 3.48 \\
4 & Compensation and Reward & 0.906 & 3.46 \\
Human Resource Management Practices & $\mathbf{0 . 9 5 6}$ & $\mathbf{3 . 4 5}$ \\
1 & Leadership & 0.881 & 3.64 \\
2 & Continuous Improvement & 0.912 & 3.53 \\
3 & Customer Satisfaction & 0.915 & 3.58 \\
4 & Employee Empowerment & 0.881 & 3.4 \\
5 & Strategic & 0.911 & 3.60 \\
Total Quality Management Practices & $\mathbf{0 . 9 6 4}$ & $\mathbf{3 . 5 5}$ \\
1 & Differentiation & 0.880 & 3.57 \\
2 & Cost Leadership & 0.901 & 3.59 \\
Competitive Advantages & $\mathbf{0 . 9 3 2}$ & $\mathbf{3 . 5 9}$ \\
\hline
\end{tabular}

\subsection{Factor Loadings Significant}

Table of descriptive statistics also mentioned loadings used in (CFA) confirmatory factor analysis. Construct with the loading of .5 are consider as solid stacking factors while the builds with the stacking of underneath .5 are considered as less are smarter to be expelled from the table.

\subsection{Convergent Validity}

Convergent validity is the degree of understanding in any event two proportions of a comparable build (Carmines \& Zeller, 1979). Convergent validity was assessed by inspection of variance mined for each factor (Fornell \& Larcker, 1981). Conferring to (Fornell \& Larcker, 1981), if the, variance extracted value is greater than 0.5 then convergent validity is established and the result is drawn that the loadings are acceptable however under 0.5 are named as less powerful for the examination. Following table shows the outcome 
Table 4. Convergent validity

\begin{tabular}{llll}
\hline VARIABLES & $\begin{array}{l}\text { Cronbach's } \\
\text { Alpha }\end{array}$ & $\begin{array}{l}\text { Composite } \\
\text { Reliability }\end{array}$ & $\begin{array}{l}\text { Average } \\
\text { Extracted (AVE) }\end{array}$ \\
\hline Recruitment and Selection & 0.902 & 0.924 & 0.670 \\
Performance Appraisals & 0.910 & 0.925 & 0.552 \\
Training and Development & 0.901 & 0.919 & 0.561 \\
Compensation and Reward & 0.906 & 0.923 & 0.571 \\
Human Resource & $\mathbf{0 . 9 5 6}$ & $\mathbf{0 . 9 5 4}$ & $\mathbf{0 . 4 7 0}$ \\
Management Practices & & 0.910 & 0.627 \\
Leadership & 0.881 & 0.927 & 0.558 \\
Continuous Improvement & 0.912 & 0.931 & 0.629 \\
Customer Satisfaction & 0.915 & 0.906 & 0.547 \\
Employee Empowerment & 0.881 & 0.927 & 0.586 \\
Strategic & 0.911 & $\mathbf{0 . 9 6 4}$ & $\mathbf{0 . 4 7 7}$ \\
Total Quality Management & $\mathbf{0 . 9 6 4}$ & 0.910 & 0.627 \\
Practices & & 0.924 & 0.670 \\
Differentiation & 0.880 & $\mathbf{0 . 9 3 2}$ & $\mathbf{0 . 5 3 4}$ \\
Cost Leadership & 0.901 & & \\
Competitive Advantages & $\mathbf{0 . 9 3 2}$ & &
\end{tabular}

\subsection{Discriminant Validity}

Discriminate validity can be characterized as any single develop when varies from different builds in the model (Carmines \& Zeller, 1979) Discriminate validity results are agreeable when the builds are having an AVE stacking more than 0.5 which implies that base half of change was took by the develop construct (Chin, 1998). Discriminate validity is built up if the components which are in askew are fundamentally higher than those qualities in off-slanting in the equal lines and sections. Discriminant Validity tests are being led so as to see whether non-related thoughts or estimations are in certainty disconnected or not. A powerful evaluation of discriminant authenticity shows that a preliminary of a thought isn't outstandingly connected with various tests proposed to measure speculatively different thoughts. The table for Discriminant Validity is given below:

Table 5. Discriminant validity (Model 1)

\begin{tabular}{|c|c|c|c|}
\hline & $\begin{array}{l}\text { Competitive } \\
\text { Advantages }\end{array}$ & $\begin{array}{l}\text { Human } \\
\text { resource } \\
\text { Management }\end{array}$ & $\begin{array}{l}\text { Total } \\
\text { Quality } \\
\text { Management }\end{array}$ \\
\hline Competitive Advantages & 0.731 & & \\
\hline $\begin{array}{lll}\text { Human } & \text { resource } & \text { Management } \\
\text { Practices } & & \end{array}$ & 0.698 & 0.686 & \\
\hline Total Quality Management Practices & 0.893 & 0.831 & 0.69 \\
\hline
\end{tabular}


Table 6. Discriminant validity (Model 2)

\begin{tabular}{|c|c|c|c|c|c|c|c|c|c|c|c|}
\hline & $\begin{array}{l}\mathbf{C} \& \\
\mathbf{R}\end{array}$ & C.I & C.L & C.S & D.A & E.E & $\mathbf{L}$ & P.A & $\begin{array}{l}\mathbf{R} \& \\
\mathbf{S}\end{array}$ & $\mathbf{S}$ & $\begin{array}{l}\text { T \& } \\
\text { D }\end{array}$ \\
\hline $\begin{array}{l}\text { Compensation \& } \\
\text { Reward }\end{array}$ & 0.76 & & & & & & & & & & \\
\hline $\begin{array}{l}\text { Continuous } \\
\text { Improvement }\end{array}$ & 0.79 & 0.75 & & & & & & & & & \\
\hline Cost Leadership & 0.65 & 0.74 & 0.82 & & & & & & & & \\
\hline Customer Satisfaction & 0.72 & 0.86 & 0.73 & 0.79 & & & & & & & \\
\hline $\begin{array}{l}\text { Differentiation } \\
\text { Advantage }\end{array}$ & 0.63 & 0.73 & 0.77 & 0.72 & 0.79 & & & & & & \\
\hline $\begin{array}{l}\text { Employee } \\
\text { Empowerment }\end{array}$ & 0.74 & 0.78 & 0.71 & 0.85 & 0.69 & 0.74 & & & & & \\
\hline Leadership & 0.85 & 0.88 & 0.68 & 0.75 & 0.67 & 0.74 & 0.79 & & & & \\
\hline Performance Appraisal & 0.78 & 0.65 & 0.52 & 0.57 & 0.54 & 0.58 & 0.71 & 0.74 & & & \\
\hline Recruitment \& Selection & 0.68 & 0.60 & 0.50 & 0.51 & 0.44 & 0.46 & 0.64 & 0.85 & 0.82 & & \\
\hline Strategic & 0.69 & 0.78 & 0.77 & 0.75 & 0.78 & 0.84 & 0.73 & 0.59 & 0.49 & 0.77 & \\
\hline $\begin{array}{l}\text { Training \& } \\
\text { Development }\end{array}$ & 0.90 & 0.68 & 0.57 & 0.64 & 0.57 & 0.67 & 0.75 & 0.85 & 0.70 & 0.61 & 0.75 \\
\hline
\end{tabular}

\subsection{Model Fit Measures}

Model fit estimates the wellness of the model in SEM-PLS is characterized by different estimates, for example, institutionalized root-mean-square leftover (SRMR), and the specific model fits like d_ULS and d_G, Normed Fit Index (NFI), and $\chi^{2}$ (Chi-square). The model fit measures comprising the deliberate estimation of both immersed model just as the evaluated model is accounted for in above Table. The soaked model evaluates the relationship between all develops. The evaluated model, then again, considers model structure and depends on absolute impact plot.

Table 7. Model Fit Measures (Model 1)

\begin{tabular}{lll}
\hline & Saturated Model & Estimated Model \\
\hline SRMR & 0.074 & 0.100 \\
d_ULS & 21.041 & 38.591 \\
d_G & n/a & n/a \\
Chi-Square & Infinite & Infinite \\
NFI & n/a & n/a \\
\hline
\end{tabular}




\section{Macrothink}

Table 8. Model Fit Measures (Model 2)

\begin{tabular}{lll}
\hline & Saturated Model & Estimated Model \\
\hline SRMR & 0.067 & 0.067 \\
d_ULS & 10.042 & 10.042 \\
d_G & 5.820 & 5.820 \\
Chi-Square & $5,135.392$ & $5,135.392$ \\
NFI & 0.591 & 0.591 \\
\hline
\end{tabular}

\subsection{Hypothesis Testing}

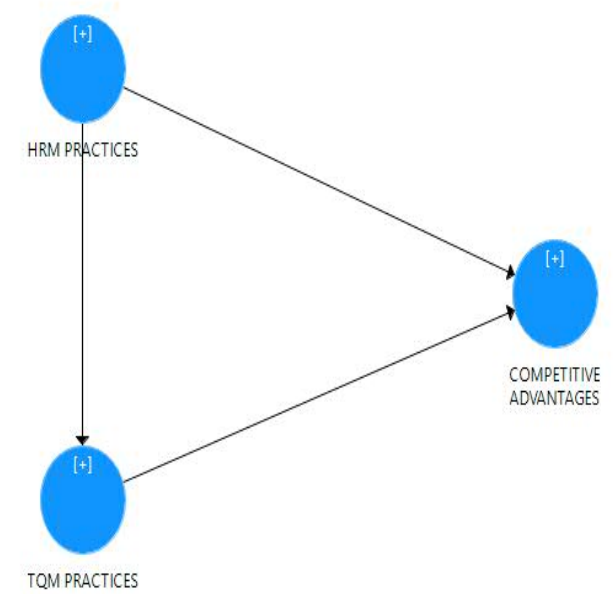

Figure 2. Path diagram (Model 1 )

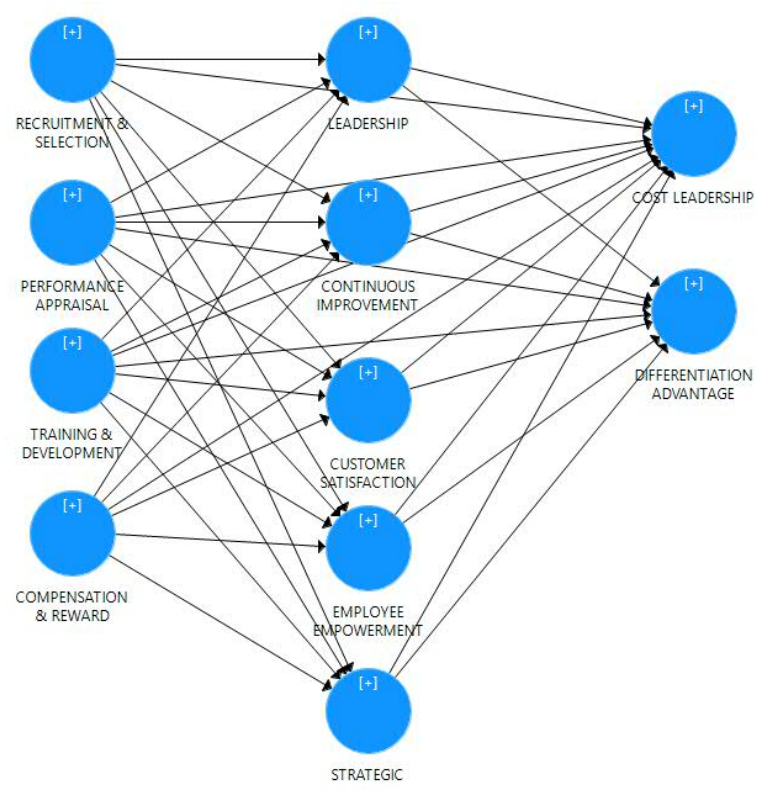

Figure 2. Path diagram (Model 2 )

In PLS-SEM, bootstrapping is one of the key walks, which gives the information of steadiness of factor rough approximation. Sub-tests are drawn wherever from the primary model including substitution, right now (Hair, Matthews, Matthews, \& Sarstedt, 2017). Bootstrapping gives the data of strength of coefficient gauge. Right now, enormous number of sub-tests are drawn from the first example with substitution (Hair et al. 2016). Subsequent to running the bootstrap standard, Smart PLS shows the t-values for basic model evaluations got from the bootstrapping methodology. The aftereffects of way coefficients for all the speculation are appeared in the accompanying table. The t-esteem more noteworthy than 1.96 $(p<.005)$ shows that the relationship is critical at 95\% certainty level $(\alpha=0.05)$. Ways indicating whether the connection among estimated and inert factors are noteworthy or not. The way outline appeared in Figure 2. 
Table 9. Test of Hypothesis

\begin{tabular}{|c|c|c|c|}
\hline HYPOTHESIS & Est. & T STATS & P VALUES \\
\hline $\begin{array}{l}\text { H0.1: There is no statistically significant effect of HRM } \\
\text { practices on competitive advantage }\end{array}$ & 0.125 & 0.404 & 0.686 \\
\hline $\begin{array}{l}\text { H0.1.1: There is no statistically significant effect of } \\
\text { recruitment and selection on cost leadership }\end{array}$ & 0.090 & 2.203 & 0.028 \\
\hline $\begin{array}{l}\text { H0.1.2: There is no statistically significant effect of } \\
\text { performance appraisal on cost leadership }\end{array}$ & 0.127 & 2.056 & 0.040 \\
\hline $\begin{array}{l}\text { H0.1.3: There is no statistically significant effect of training } \\
\text { and development on cost leadership }\end{array}$ & 0.136 & 0.809 & 0.419 \\
\hline $\begin{array}{l}\text { H0.1.4: There is no statistically significant effect of } \\
\text { compensation and reward on Cost leadership }\end{array}$ & 0.140 & 0.134 & 0.894 \\
\hline $\begin{array}{l}\text { H0.1.5: There is no statistically significant effect of } \\
\text { recruitment and selection on differentiation }\end{array}$ & 0.078 & 0.188 & 0.851 \\
\hline $\begin{array}{l}\text { H0.1.6: There is no statistically significant effect of } \\
\text { performance appraisal on differentiation }\end{array}$ & 0.101 & 0.162 & 0.871 \\
\hline $\begin{array}{l}\text { H0.1.7: There is no statistically significant effect training } \\
\text { and development on differentiation }\end{array}$ & 0.105 & 0.401 & 0.689 \\
\hline $\begin{array}{l}\text { H0.1.8: There is no statistically significant effect of } \\
\text { compensation and reward on differentiation }\end{array}$ & 0.111 & 5.773 & 0.000 \\
\hline $\begin{array}{l}\text { H0.2: There is no statistically significant effect of TQM } \\
\text { practices on competitive advantage }\end{array}$ & 0.099 & 9.001 & 0.000 \\
\hline $\begin{array}{l}\text { H0.2.1: There is no statistically significant effect of } \\
\text { leadership on cost leadership }\end{array}$ & 0.124 & 0.294 & 0.769 \\
\hline $\begin{array}{l}\text { H0.2.2: There is no statistically significant effect of } \\
\text { continuous improvement on cost leadership }\end{array}$ & 0.146 & 0.838 & 0.402 \\
\hline $\begin{array}{l}\text { H0.2.3: There is no statistically significant effect of } \\
\text { customer satisfaction on cost leadership }\end{array}$ & 0.117 & 1.978 & 0.048 \\
\hline $\begin{array}{l}\text { H0.2.4: There is no statistically significant effect of } \\
\text { employee empowerment on cost leadership }\end{array}$ & 0.131 & 0.512 & 0.609 \\
\hline $\begin{array}{l}\text { H0.2.5: There is no statistically significant effect strategic } \\
\text { on cost leadership }\end{array}$ & 0.110 & 4.658 & 0.000 \\
\hline $\begin{array}{l}\text { H0.2.6: There is no statistically significant effect leadership } \\
\text { on differentiation }\end{array}$ & 0.118 & 0.466 & 0.641 \\
\hline $\begin{array}{l}\text { H0.2.7: There is no statistically significant effect of } \\
\text { continuous improvement on differentiation }\end{array}$ & 0.135 & 0.411 & 0.681 \\
\hline $\begin{array}{l}\text { H0.2.8: There is no statistically significant effect of } \\
\text { customer satisfaction on differentiation }\end{array}$ & 0.117 & 2.966 & 0.003 \\
\hline $\begin{array}{l}\text { H0.2.9: There is no statistically significant effect of } \\
\text { employee empowerment on differentiation }\end{array}$ & 0.114 & 1.895 & 0.059 \\
\hline $\begin{array}{l}\text { H0.2.10: There is no statistically significant effect of } \\
\text { strategic on differentiation }\end{array}$ & 0.105 & 5.524 & 0.000 \\
\hline H0.3: There is no statistically significant effect of HRM 0 & $\mathbf{0 . 0 3 8}$ & 21.069 & 0.000 \\
\hline
\end{tabular}


practices on TQM practices

H0.3.1: There is no statistically significant effect of $0.078 \quad 0.389$ recruitment and selection on leadership

H0.3.2: There is no statistically significant effect of performance appraisals on leadership

H0.3.3: There is no statistically significant effect of training and development on leadership

H0.3.4: There is no statistically significant effect of compensation and reward on leadership

H0.3.5: There is no statistically significant effect of $0.080 \quad 1.096$ recruitment and selection on continuous improvement

performance appraisals on continuous improvement

H0.3.8: There is no statistically significant effect of compensation and reward on continuous improvement

H0.3.9: There is no statistically significant effect of recruitment and selection on customer satisfaction

H0.3.10: There is no statistically significant effect of performance appraisals on customer satisfaction

H0.3.11: There is no statistically significant effect of training and development on customer satisfaction

H0.3.12: There is no statistically significant effect of compensation and reward on customer satisfaction

H0.3.13: There is no statistically significant effect of recruitment and selection on employee empowerment

H0.3.14: There is no statistically significant effect of performance appraisals on employee empowerment

H0.3.15: There is no statistically significant effect of training and development on employee empowerment

H0.3.16: There is no statistically significant effect of compensation and reward on employee empowerment

H0.3.17: There is no statistically significant effect of recruitment and selection on strategic

H0.3.18: There is no statistically significant effect performance appraisals on strategic

H0.3.19: There is no statistically significant effect training and development on strategic

H0.3.20: There is no statistically significant effect of compensation and reward on strategic 
It is clearly seen from the above Table (9) that large $p$-value $(>0.05)$ indicates weak evidence against the null hypothesis (H0.1), so in banking industry of Pakistan, "There is no statistically significant effect at $(\alpha \leq 0.05)$ of human resource management practices on competitive advantages" at a confidence interval level of $97.5 \%$.

However a small $p$-value (typically $\leq 0.05$ ) indicates strong evidence against the null hypothesis, so we reject the null hypothesis (H0.2 \& H0.3). (Table 11) indicates that in growing banking industry of Pakistan, there is definitely statistically a significant effect of total quality management practices on competitive advantage and there is also statistically a significant effect of human resource management practices on total quality management practices at $(\alpha \leq 0.05)$ and confidence interval level of $97.5 \%$.

The above Table (9) also shows the results of relationship among the sub variables.

As shown in Table (9) only two sub hypothesis of H0.1 (There is no statistically significant effect at $(\alpha \leq 0.05)$ of human resource management practices on competitive advantage) has small $p$-value (typically $\leq 0.05$ ) indicates strong evidence against the null hypothesis, so we reject the null hypothesis (H0.1.1 \& H0.1.2).

So in banking industry of Pakistan, There is statistically a significant effect of recruitment \& selection on Cost Leadership and there is also a statistically significant effect of performance appraisals on Cost Leadership.

As shown in Table (9) only four sub hypothesis of H0.2: (There is no statistically significant effect at $(\alpha \leq 0.05)$ of total quality management practices on competitive advantage)has small $p$-value (typically $\leq 0.05$ ) indicates strong evidence against the null hypothesis, so we reject the null hypothesis $\left(\mathrm{H}_{0.2 .3}, \mathrm{H} 0 \cdot 2.5\right.$, and $\left.\mathrm{H} 0.2 .8 \& \mathrm{H} 0 \cdot 2.10\right)$.

Thus in banking industry of Pakistan, There is statistically a significant effect of customer satisfaction on Cost Leadership, There is statistically a significant effect of strategic on Cost Leadership, There is statistically a significant effect of customer satisfaction on Differentiation and there is statistically a significant effect of strategic on Differentiation.

As shown in Table (9) only eight sub hypothesis of H0.3: There is no statistically significant effect at $(\alpha \leq 0.05)$ of human resource management practices on total quality management practices has small $p$-value (typically $\leq 0.05$ ) indicates strong evidence against the null hypothesis, so we reject the null hypothesis (H0.3.3, H0.3.4, H0.3.5, H0.3.8, H0.3.9, H0.3.16, $\mathrm{H} 0.3 .18$ \& $\mathrm{H} 0.3 .20)$.

Hence in banking industry of Pakistan, There is a statistically significant effect of training and development on leadership, There is a statistically significant effect of compensation and reward on leadership. There is no statistically significant effect of training and development on continuous improvement. There is a statistically significant effect of compensation and reward on continuous improvement, There is a statistically significant effect of compensation and reward on customer satisfaction. There is a statistically significant effect of compensation and reward on employee empowerment. There is a statistically significant effect performance appraisals on strategic and There is a statistically significant effect of compensation and reward on strategic. 
Table 10. Indirect effect

\begin{tabular}{llll}
\hline Relation & Est. & T Stats & P Values \\
\hline Compensation \& Reward $\geq$ Strategic $\geq$ Cost Leadership & 0.115 & 3.372 & 0.001 \\
Performance Appraisal $\geq$ Strategic $\geq$ Cost Leadership & 0.082 & 1.974 & 0.049 \\
Compensation \& Reward $\geq$ Customer Satisfaction $\geq 0.101$ & 2.565 & 0.011 \\
$\begin{array}{l}\text { Differentiation Advantage } \\
\text { Compensation \& Reward } \geq \text { Strategic } \geq \text { Differentiation }\end{array}$ & 0.117 & 3.777 & 0.000 \\
Advantage & & & \\
HRM Practices $\geq$ TQM Practices $\geq$ Competitive & 0.097 & 7.352 & 0.000 \\
Advantages & & & \\
\hline
\end{tabular}

Above Table (10) shows that the specific indirect effect of the three variable and it state that there is a strong relationship among the HRM practice, TQM practices and Competitive Advantages. This result indicates the mediation effect of TQM practices, conclusively in banking industry of Pakistan there is an impact of HRM practices on TQM practices, TQM practices on Competitive Advantages and ultimately there is also an impact of HRM practices on Competitive Advantages.

Above table also indicates the specific indirect effect, that the strategic factor of TQM has a mediating effect in between compensation \& reward and cost leadership, also in between performance appraisal and cost leadership and in between compensation \& reward and differentiation advantage as well. One of the result also indicates that there is also a strong relation among compensation $\&$ reward, customer satisfaction and differentiation advantage.

\section{Discussions}

This study found that HR practices insignificantly influence competitive advantage, in going further the researcher identified that, HR (recruitment, and selection) has a significant impact on the competitive advantage, thus providing empirical support for sub H0.1.1. This shows that HR (recruitment \& selection) is related with the choice of people who are roused, qualified and the opportune individual for a particular activity. On the off chance that such people are furnished with the vital motivators, their inspiration increments; from an association's perspective, this may upgrade the maintenance of value representatives and hence improve individual or potentially authoritative execution (Sanchez-Marin \& Baixauli-Soler, 2015).

Sub H0.1.6 predicted that performance appraisal has an insignificant impact on the competitive advantage (differentiation) of Bank. This hypothesis contracted with the recent research, (Aladwan, Bhanugopan, \&\& D'Netto, 2015) stated that "developing an evaluation system that accurately reflects employee satisfaction and commitment is a crucial and difficult task." (Matić, 2008) Added that laborers who can coordinate their work esteems with their work environment evaluation framework have a more prominent authoritative duty and are more averse to leave the association. (Van Vianen, Pater, \&\& Dijk, 2007) Added that construing from person-organization fit hypothesis, one could conjecture that human conduct is a component of both the individual and his/her condition. Further, Sub H0.1.3 predicted that training and development have no significant impact on the competitive advantage. This 
hypothesis also received empirical support; recent findings by (Sanchez-Marin \& Baixauli-Soler, 2015) suggested that "training and development improve the knowledge, skills, and abilities of a firm's current and potential employees." Training and development were positively linked with organizational commitment (Feldman \& Ng, 2007). Further, (Tzafrir, 2006) added that training and development was closely associated with work values, performance and organizational commitment. However, this study found that the relationship is not exists. This study uncovered no significant relationship between compensation and rewards and the competitive advantage. This is surprising as existing theoretical framework suggested that compensation and reward policies have a positive and significant impact on related organizational concepts, for example, organizational commitment and organizational performance (Aladwan, Bhanugopan, \&\& D'Netto, 2015). Intuitively speaking, the researchers expected such a relationship with competitive advantage, because the competitive advantage is a construct similar to the aforementioned ones. Notwithstanding, in an "ever-competitive local and global business environment, many organizations are trying to develop effective reward strategies that are directly linked to the enhancement of employee and organizational performance" (Milne, 2007; Yeganeh \& Su, 2008). (Huselid, 1995) Noted that "performance-based compensation and merit-based promotion are ingredients in organizational incentive systems that serve to encourage individual performance and retention." The two compensation and reward system should be balanced to have the desired organizational outcome.

This study's findings led the researchers to reject sub H0.1.4; a compensation and reward system did not enhance competitive advantage. This study also found that TQM practices has significant relationship with competitive advantage, in going further the researcher identified that, Leadership has an insignificant impact on the competitive advantage, thus providing empirical support for this. This shows that leadership is what we call the most important resource that holds in the absence of which all other resources, and it manages to cope with changes and from a firm's point of view, this may enhance the organizational performance (Helmrich, 2015). The researchers suggest that leadership needs to be improved in banks, as this mitigate competitive advantage due to an insignificant relationship. It was also predicted that continuous improvement has an insignificant impact on the competitive advantage of Bank. The finding contradict with the research of (Singh \& Singh, 2014) .

Further, customer satisfaction has a significant impact on the competitive advantage. This also received empirical support; a plausible explanation can be inferred from prior work. Customer satisfaction is one of the critical success factors in today's competitive business environment as it influences companies' market share and customer retention (Ooi, Lin, Tan, $\&$ Chong, 2011). Customers are often considered to be the most important asset of any organization; thus, the success of an organization depends on its number of customers (Iakov, 2013).

This study uncovered no significant relationship between employee empowerment and the competitive advantage. This is surprising as existing theoretical framework suggested that employee empowerment as a strategy that enhance organizational performance; it also helps with developing a flexible organization that can be capable of adapting to a changing external environment (Ferit, 2015). When employees experience empowerment and see the impact of 
their jobs are having on the organization, they identify more with the goals of the organization and as a result are more committed to it (Elloy, 2012). This study's findings led the researchers to reject H0.2.4 and H0.2.9; Employee empowerment did not enhance competitive advantage. Result shows that strategic factor of TQM Practices has a significant effect on competitive advantages.

This study also found that TQM practices has significant relationship with HRM practices. More specifically compensation \& reward factor of HRM practices has a significance effect on almost all factors of TQM practices. This hypothesis received empirical support, (Hataani \& Mahrani, 2013) showed how TQM significantly enhances the HRM practices. In testing the hypothesis, their outcome shows that TQM practices have positive and huge effect on HRM practices. This clarification for this is execution of TQM (at the tallness as per the possibilities of businesses) bolsters a decent authority, a conservative group, representative commitment and the opening of data frameworks. (Abu-Doleh, 2012) Examined a few key highlights in particular preparing and advancement, worker profession improvement, and enrolling and determination which seem to have the best impact on the usage of TQM practices.

\section{Conclusion}

This study examined the role of HR and TQM practices in influencing the competitive advantage in banking industry of Pakistan. We presented and diagnosed a model that included two precedents of competitive advantage (cost advantage and differentiation advantage) that have not been considered until now.

From the results we concluded that banking industry should focus on TQM practices to achieve competitiveness in the market. Service industry like banks should be clear about service quality. In banking industry customer wants delight and satisfaction, for this banking sector in Pakistan has improved their TQM practices and gain a sustainable market edge. To improve and make more effective and efficient TQM practices and service quality, human resource can play a vital role. Nowadays HRM practices has a significant impact on TQM practices. Thus, it is very much clear that in banking industry of Pakistan competitive advantages can be archive by implementing best HRM practices and also by applying the mediator role of TQM practices.

From the realistic attitude, this take a look at has six foremost implications.

First, there ought to be greater intensified attention closer to increasing the awareness towards HRM role in banking sector. Consequently, HRM department can efficaciously carry out better, and personnel can recognize the function of the department.

Second, HRM department need to pay greater attention about improving the repayment and reward machine in a way to enhance the overall quality management implementation and enhance competitive advantage, the branch must pay attention on candidate talents along with potential to resolve trouble and capacity to paintings inside team (see e. g. (Khalayleh, Masa'deh, \& Al-Lozi, 2017)).

Third, TQM department ought to pay attention on worker empowerment to improve great and performance software in banking sector, and allow all worker to speak about new problems so as reach great nice. 
Fourth, businesses ought to design and expand products to meet marketplace wishes thru non-stop observe communique with clients and decide their current requirements, and destiny expectancies. This can increase the customer base and as a result boom marketplace share.

Fifth, employer have to maintain education packages explicitly designed to general high-quality control on a normal basis to all employees. This can ensure better implementation of pleasant assurance practices and hence improve the competitive advantage. Finally, companies must spread the attention of pleasant between employees and make them a part of the enterprise's tradition (see e. g. (Shannak \& Obeidat, 2012), and in activate innovation (see e. g. (Obeidat, Tarhini, \& Aqqad, The impact of intellectual capital on innovation via the mediating role of knowledge management: a structural equation modeling approach, 2017)).

\section{Limitations and Future Recommendations}

Furthermore, this study is restricted to employee of Pakistan and the evidence of results are based on banking sector. More specifically results of this study are based on private sector. Responses are limited (closed-ended) and participant could not answer in more detail. Result of this study may be changes if study were conducted in other business sector and region. Public sector is recommended for future research. It is suggested that organizations should develop a liaison with the academic institutions to promote research activities in Pakistan and it will be helpful for better response and results.

\section{References}

Abd Aziz, N., \& Samad, S. (2016). The influence of innovation and financial stability on the competitive advantage of Malaysian SMEs. Terengganu International Business and Economics Conference, 163-177.

Abdul-Halim, H., Che-Ha, N., Geare, A., \& Ramayah, T. (2016). The pursuit of HR outsourcing in an emerging economy: The effects of HRM strategy on HR labour costs. Canadian Journal of Administrative Sciences/Revue Canadienne des Sciences de l'Administration, 33(2), 153-168. https://doi.org/10.1002/cjas.1370

Abdullah, H., Mohamed, Z., Othman, R., \& Uli, J. (2009). The effect of sourcing strategies on the relationship between competitive strategy and firm performance. International Review of Business Research Papers, 5(3), 346-361.

Absar, N. (2012). Recruitment \& selection practices in manufacturing firms in Bangladesh. The Indian Journal of Industrial Relations, 47(3), 436-449.

Absar, N., Nimalathasan, B., \& Mahmood, M. (2012). HRM-market performance relationship: evidence from Bangladeshi organizations. South Asian Journal of Global Business Research, l(2), 238-255. https://doi.org/10.1108/20454451211252750

Abualoush, S. H., Obeidat, A. M., Tarhini, A., Masa'deh, R., \& Al-Badi, A. (2018b). The role of employees' empowerment as an intermediary variable between knowledge management and information systems on employees' performance. VINE Journal of Information and Knowledge Management Systems, 48(2), 217-237. https://doi.org/10.1108/VJIKMS-08-2017 $-0050$

Abualoush, S., B. K., \& Alrowwad, A. (2018a). The role of knowledge management process and intellectual capital as intermediary variables between knowledge management 
infrastructure and organization performance. Interdisciplinary Journal of Information, Knowledge, and Management, 13, 279-309. https://doi.org/10.28945/4088

Abu-Doleh, J. D. (2012). Human resource management and total quality management linkage-rhetoric and reality. International Journal of Commerce and Managemen. https://doi.org/10.1108/10569211211260300

Addae-Korankye, A. (n.d.). Total quality management (TQM): a source of competitive advantage. a comparative study of manufacturing and service firms in Ghana. International Journal of Asian Social Science, 3(6).

Adeoti, J. O. (2003). The impact of Total quality Management on Banks performance in Nigeria. Journal of Department of business administration, 3.

Adetunji, A. (2015). Recruitment and selection process, element of organizational social capital building: A study of Nigeria medium enterprises human resources practitioners. International Journal of Research in Economics and Social Science, 5(9), 50-61.

Adil, M. S. (2015). Strategic human resource management practices and competitive priorities of the manufacturing performance in Karachi. Global Journal of Flexible Systems Management, 16(1). https://doi.org/10.1007/s40171-014-0084-7

Ahlvik, C., Smale, A., \& Sumelius, J. (2016). Aligning corporate transfer intentions and subsidiary HRM practice implementation in multinational corporations. Journal of World Business, 51(3), 343-355. https://doi.org/10.1016/j.jwb.2015.04.003

Al Azmi, N., Al-Lozi, M., Al-Zu'bi, Z., \& Dahiyat, S. (2012). Patients attitudes toward service quality and its. impact on their satisfaction in physical therapy in KSA hospitals European Journal of Social Sciences, 34(2), 300-314. https://doi.org/10.1108/IJOA11-2014-0822

Aladwan, K., Bhanugopan, R., \&\& D'Netto, B. (2015). The effects of human resource management practices on employees' organisational commitmen. International Journal of Organizational Analysis.

Albrecht, S., Bakker, A., Gruman, J., Macey, W., \& Saks, A. (2015). Employee engagement, human resource management practices and competitive advantage. Journal of Organizational Effectiveness: People and Performance, 2(1), 7-35. https://doi.org/10.1108/JOEPP-08-20140042

Al-dalahmeh, M., Khalaf, R., \& Obeidat, B. (2018). The effect of employee engagement on organizational performance via the mediating role of job satisfaction: The case of IT employees in Jordanian banking sector. Modern Applied Science, 12(6), 17-43. https://doi.org/10.5539/mas.v12n6p17

Aldmour, R., Masa'deh, R., \& Obeidat, B. (2017). Factors influencing the adoption and implementation of HRIS applications: Are they similar. International Journal of Business Innovation and Research, 14(2), 139-167. https://doi.org/10.1504/IJBIR.2017.086276

Al-Dmour, R., Obeidat, B., \& Almajali, D. (2015). The practice of HRIS applications in business organizations in Jordan: An empirical study. 4th Scientific \& Research.

Alenezi, H., Tarhini, A., Alalwan, A., \& Al-Qirim, N. (2017). Factors affecting the adoption of e-government in Kuwait: a qualitative study. Electronic Journal of e-Government, 15(2), 
84-102.

Almajali, D., \& Al-Lozi, M. (2016). Determinants of the actual use of e-learning systems:An empirical study on Zarqa University in Jordan. Journal of Social Sciences, 5(2), 172-200. https://doi.org/10.25255/jss.2016.5.2.172.200

Al-Mansour, A. H. (2007). Application of TQM to financial services.

Aragon-Sanchez, A., \& Nevers Esteban-Lloret, N. (2010). Training in the Spanish company: Just improving firm performance? CJC BUSINESS AND SOCIETY REVIEW, 26, 34-56.

Aswathappa, K. (2008). Human Resource Management: Text and Cases. Dehli: Tata McGraw-Hill Publishing Company Limited.

Bae, J., \& Lawler, J. J. (2000). Organizational and HRM strategies in Korea: Impact on firm performance in an emerging economy. Academy of Management Journal, 43(3). https://doi.org/10.5465/1556407

Baron, R. M., \& Kenny, D. (1986). The moderator-mediator variable distinction in social psychological research: Conceptual, strategic, and statistical considerations. Journal of Personality and Social Psychology, 1173-1182. https://doi.org/10.1037/0022-3514.51.6.1173

Bhatt, P., \& Reddy, C. (2011). HRM practices and its impact on performance - exploratory literature review in the context of indiansmes. NJRIM, 1(2), 73-87.

Bhattacharjee, S., \& Bhattacharjee, B. (2015). Competitive advantage through HRM practices in MSMEs. International Journal of Management and Humanities (IJMH), 1(7).

Bitner, J., \& Zeithaml, A. (2003). Service Marketing (3rd ed.). New Dehli: Tata McGraw Hill. Blythe, J. (2009). Principles and Practice of Marketing (2nd ed.). Cengage Learning.

Blythe, J. (2009). Principles and Practice of Marketing (2nd ed.). Cengage Learning.

Boon, K., Arumugam, V., Safa, S., \& Abu Bakar, N. (2007). HRM and TQM: Association with job involvement. Personnel Review, 36(6), 939-962. https://doi.org/10.1108/0048 3480710822445

Brah, A., \& Lim, Y. (2006). The effects of technology and TQM on the performance of logistics companies. International Journal of Physical Distribution \& Logistics Management, 36(3), 192-209. https://doi.org/10.1108/09600030610661796

Budhwar, P. S., Chand, M., \& Katou, A. A. (2007). The impact of HRM practices on organisational performance in the Indian hotel industry. Employee relations, 29(6), 576-594. https://doi.org/10.1108/01425450710826096

Cantarello, S., Filippini, R., \& Nosella, A. (2012). Linking human resource management practices and customer satisfaction on product quality. The international journal of human resource management, 23(18). https://doi.org/10.1080/09585192.2012.665064

Carmines, E. G., \& Zeller, R. (1979). Reliability and Validity Assessment. Sage publication, Inc. https://doi.org/10.4135/9781412985642

Caroly, S., Coutarel, F., Landry, A., \& Mary-Cheray, I. (2010). Sustainable MSD prevention: management for continuous improvement between prevention and production. Applied Ergonomics, 41, 591-599. https://doi.org/10.1016/j.apergo.2009.12.016

Chen, C., Li, Y., \& Shady, D. (2010). From value stream mapping toward a lean/sigma continuous improvement process: an industrial case study. International Journal of 
Production Research, 48(4), 1069-1086. https://doi.org/10.1080/00207540802484911

Chin, W. W. (1998). The Partial least squares approach to structural equation modeling. Mahwah, NJ,US: Lawrence Erlbaum Associates Publishers.

Chiu, R. K., Luk, V. W., \& Tang, T. L. (2002). Retaining and motivating employees. Personnel Review. https://doi.org/10.1108/00483480210430346

Coad, A., \& Teruel, M. (2013). Inter-firm rivalry and firm growth: Is there any evidence of direct competition between firms? Industrial and Corporate Change, 22(2), 397-425. https://doi.org/10.1093/icc/dts018

Collins, C. J., \& Smith, K. G. (2006). Knowledge exchange and combination: The role of human resource practices in the performance of high-technology firms. Academy of Management JournaL, 49(3), 544-560. https://doi.org/10.5465/amj.2006.21794671

David Jobber, J. F. (2007). Fundamento de Mrketing.

Delaney, J. T., \& Huselid, M. A. (1996). The impact of human resource management practices on perceptions of organizational performance. Academy of Management Journal, 39(4). https://doi.org/10.2307/256718

Dessler, G. (2017). Human Resource Management (15th ed.). Pearson Education Limited 2017.

Douglas, T., \& Judge, W. (2001). Total quality management implementation and competitive advantage: the role of structural control and exploration. The Academy of Management Journal, 44(1), 158-169. https://doi.org/10.2307/3069343

Dubey, R., Singh, T., \& Ali, S. S. (2015). The mediating effect of human resource on successful total quality management implementation. Benchmarking: An International Journal. https://doi.org/10.1108/BIJ-08-2013-0083

Elloy, D. (2012). Effects of ability utilization, job influence and organization commitment on employee empowerment: an empirical study. International Journal of Management, 29(2), 627-632.

Elrehail, H., Harazneh, I., Abuhjeeleh, M., Alzghoul, A., Alnajdawi, S., \& Ibrahim, H. M. (2019). Employee satisfaction, human resource management practices and competitive advantage. European Journal of Management and Business Economics.

Feldman, D. C., \& Ng, T. W. (2007). Careers: Mobility, embeddedness, and success. Journal of management, 33(3), 350-377. https://doi.org/10.1177/0149206307300815

Ferguson, K. L., \& Reio, T. G. (2010). Human resource management systems and firm performance. Journal of Management Development. https://doi.org/10.1108/0262171101 1039231

Ferit, O. (2015). Mediating effect of job satisfaction in the relationship between psychological empowerment and job performance. Theoretical \& Applied Economics, Autumn, 22(3), 111-136.

Fey, C. F., Björkman, I., \& Pavlovskaya, A. (2000). The effect of human resource management practices on firm performance in Russia. International Journal of Human Resource Management, 11(1). https://doi.org/10.1080/095851900339963

Fornell, C., \& Larcker, D. (. (1981). Evaluating structural equation models with unobservable 


\section{Macrothink}

Human Resource Research ISSN 1948-5441 2020, Vol. 4, No. 1

variables and measurement error. Journal of Marketing Research, 39-50. https://doi.org/10.1177/002224378101800104

Friend, R. (2015). Contextual examination of TQM practices and competitive advantage in the Malaysian manufacturing sectors. Proceedings of the 2nd Word Virtual Conference on Social and Behavioral Sciences, (pp. 1-4). Kuala Lumpur.

Gamble, J., Strickland, A., \& Thompson, A. (2007). Crafting \& executing strategy. New York: McGraw-Hill (2007).

Gareche, M., Hosseini, S., \& Taheri, M. (2013). A comprehensive literature review in competitive advantages of businesses. International Journal of Advanced Studies in Humanities and Social Science, 1(11), 2210-2225.

Gooderham, P., Ringdal, K., \& Parry, E. (2006,September). The impact of human resource management practices on the performance of European firms. In Copenhagen Business School Conference on HRM and Knowledge-Related Performance.

Gopinath, R., \& Shibu, S. (2016). Compensation management and welfare measure influencing job satisfaction. A study with reference to Bsnl, Madurai Ssa.

Greasley, K., Bryman, A., Dainty, A., Price, A., Soetanto, R., \& King, N. (2005). Employee perceptions of empowerment. Employee Relations, 27(4), 354-368. https://doi.org/10.1108/ 01425450510605697

Hair, J. F., Matthews, L. M., Matthews, R. M., \& Sarstedt, M. (2017). PLS-SEM or CB-SEM: updated guidelines on which method to use. Int. J. Multivariate Data Analysis, 107-123. https://doi.org/10.1504/IJMDA.2017.10008574

Harel, G. H., \& Tzafrir, S. S. (1999). The effect of human resource management practices on the perceptions of organizational and market performance of the firm. Human Resource Management: Published in Cooperation with the School of Business Administration, The University of Michigan and in alliance with the Society of Human Resources Management, 38(3). https://doi.org/10.1002/(SICI)1099-050X(199923)38:3<185::AID-HRM2>3.0.CO;2-Y Harel, G., \& Tzafrir, S. (1996). The Effects of Human Resource Management Practices on the Perceptions of Organizational and Market Performance of the Firm. Human Resource Management, 38. https://doi.org/10.1002/(SICI)1099-050X(199923)38:3<185::AID-HRM2> 3.0.CO;2-Y

Hataani, L., \& Mahrani, S. (2013). Strategic human resource management practices: mediator of total quality management and competitiveness (a study on small and medium enterprises in kendari southeast sulawesi). International Journal of Business and Management Invention, 2(1).

Hayes, A. F. (2013). Introduction to mediation, moderation, and conditional process analysis: A regression-based approach. New York, US: Guilford Press.

Helmrich, B. (2015). 30 ways to define leadership. Retrieved from Business News Daily: http://www.businessnewsdaily.com/3647-leadership-definition.html

Herzallah, A., Gutiérrez-gutiérrez, L., \& Rosas, J. (2014). Total quality management practices, competitive strategies and financial performance: the case of the Palestinian industrial SMEs. Total Qual. Manag. Bus. Excell, 25(5-6), 635-649. https://doi.org/10.1080/14783363.2013.82 
4714

Hitt, M., R., H., \& Kim, H. (1997). Strategic Management: Competitiveness and Globalization, (2nd ed.). West Publishing Company.

Hooley, G., Saunders, J., Piercy, N., \& Nicoulaud, B. (2008). Marketing Strategy and Competitive Positioning (4th ed.). Prentice Hall.

Hough, J., T. J., Strickland, J., \& Gamble, E. (2011). Crafting and executing strategy: Creating sustainable high performance in South Africa: Texts, reading and cases (2nd ed.). MacGraw Hill.

Huselid, M. A. (1995). The impact of human resource management practices on turnover, productivity, and corporate financial performance. Academy of Management Journal, 38(3). https://doi.org/10.5465/256741

Hyde, J., Stup, R., \& Holden, L. (2008). The effect of human resource management practices on farm profitability: an initial assessment. Economics Bulletin, 17(12), 1-10.

Iakov, B. (2013). Customer satisfaction in the operator's market of the Israeli Hi-Tech. International Conference "Marketing-from information to decision".

Ireland, R., Hokisson, R., \& Hitt, M. (2011). The management of strategy-International edition (9th ed.). Cengage Learning.

Irfan, S. M., Ijaz, A., Kee, D. M., \& Awan, M. (2012). Improving operational performance of public hospital in Pakistan: A TQM based approach. World Applied Sciences Journal, 19(6).

Izvercian, M., Radu, A., Ivascu, L., \& Ardelean, B. (2014). The impact of human resources and total quality management on the enterprise. Procedia-Social and Behavioral Sciences, 124. https://doi.org/10.1016/j.sbspro.2014.02.456

Jiménez-Jiménez, D., \& Martínez-Costa, M. (2009). The performance effect of HRM and TQM: A study in Spanish organization. International Journal of Operations \& Production Management, 29(12), 266-289. https://doi.org/10.1108/01443570911005992

Jobber, D. (2007). Principles and Practice of Marketing (5th ed.). McGraw Hill.

Joseph, K. E., \& Dai, C. (. (2009). HRM practices and organizational performance: An empirical analysis. International Journal of Business and Management, 4(8), 117-127. https://doi.org/10.5539/ijbm.v4n8p117

Jung, N. (2009). Competitive strategy, TQM practice, and continuous improvement of international project management. International Journal of Quality \& Reliability Management, 26(2), 164-183. https://doi.org/10.1108/02656710910928806

Katou, A. A., \& Budhwar, P. S. (2006). Human resource management systems and organizational performance: a test of a mediating model in the Greek manufacturing context. International Journal of Human Resource Management, 17(7). https://doi.org/10.1080/ 09585190600756525

Keegan, W. J., \& Green, M. C. (2008). Global Marketing.

Keller, K., Aperia, T., \& Georgson, M. (2008). Strategic Brand Management, A European Perspective. Prentice Hall.

Khalayleh, W., Masa'deh, R., \& Al-Lozi, M. (2017). Administrative empowerment and its role on the work teams Performance: A literature review. Journal of Social Sciences 
(COES\&RJ-JSS), 6(4), 851-868. https://doi.org/10.25255/jss.2017.6.4.851.868

Khwaldeh, S., Al-Hadid, I., \& Alrowwad, A. (2017). The association between e-services web portals information quality and ICT competence in the Jordanian universities. Asian Social Science, 13(3), 156-169. https://doi.org/10.5539/ass.v13n3p156

Kimolo, K. (2019). The relationship between employee empowerment practices and employee performance in regional development authorities in Kenya.

Kulkarni, P. (2013). A literature review on training \& development and quality of work life. India malt house press Ltd.

Kumar, P. C., \& Bennett, D. (2010). Managing enterprise resource planning projects. Business Process Management Journal, 16(2), 282-296. https://doi.org/10.1108/1463715 1011035606

Kumar, R. (2012). Human resource management and total quality management -an important aspect in the bank. G.J. I.S.S., 1(1), 14-20.

Lall, S., \& Teubal, M. (1998). arket-stimulating” technology policies in developing countries: A framework with examples from East Asia. World development, 26(8, 1369-1385. https://doi.org/10.1016/S0305-750X(98)00071-0

Lazim, Y., Azizanm, N., \& Sorooshianm, S. (2015). How are the performance of small businesses influenced by HRM practices and governmental support? Mediterranean Journal of Social Sciences, 6(1), 97-108. https://doi.org/10.5901/mjss.2015.v6n1p97

Lee, F. H., \& Lee, F. Z. (2007, November). The relationships between HRM practices, Leadership style, competitive strategy and business performance in Taiwanese steel industry. Proceedings of the 13th Asia Pacific Management Conference, 2007, pp. 953-971. Melbourne, Australia.

Li, J. M., \& Wu, H. H. (2008). Improving service quality and organisation performance through human resource practices. A case study. Total Quality Management, 19(9), 969-985. https://doi.org/10.1080/14783360802227787

Ling, G., Yeo, S., \& Lim, K. (2016). Understanding customer satisfaction of internet banking: a case study in Malacca. Procedia Economics and Finance, 37, 80-85. https://doi.org/10. 1016/S2212-5671(16)30096-X

Malik, O. R., \& Kotabe, M. (2009). Dynamic capabilities, government policies, and performance in firms from emerging economies: Evidence from India and Pakistan. Journal of Management Studies, 46(3), 421-450. https://doi.org/10.1111/j.1467-6486.2008.00817.x

Marín García, J. A., Medina López, C., \& Alfalla Luque, R. (2012). Is worker commitment necessary for achieving competitive advantage and customer satisfaction when companies use HRM and TQM practices? Universia Business Review, 36.

Mark, H. (2011). Human Resource Management and Competitive Advantage. Retrieved from http:/ocean.otr.usm.edu/ w813743/364chapter1.html

Masa'deh, R., Alrowwad, A., Alkhalafat, F., Obeidat, O., \& Abualoush, S. (2018). The role of CSR in enhancing firm performance from the perspective of IT employees in Jordanian banking sector: The mediating effect of transformational leadership. Modern Applied Science, 12(7), 1-26. https://doi.org/10.5539/mas.v12n7p1 


\section{Ml Macrothink}

Masa'deh, R., Almajali, D., Alrowwad, A., \& Obeidat, B. (2019). The Role of Knowledge Management Infrastructure In Enhancing Job Satisfaction: A Developing Country Perspective. Interdisciplinary Journal of Information, Knowledge \& Management, 1-25.

Matić, J. L. (2008). Cultural differences in employee work values and their implications for management. Management: Journal of Contemporary Management Issues, 13(2), 93-104.

Milne, P. (2007). Motivation, incentives and organisational culture. Journal of Knowledge Management. https://doi.org/10.1108/13673270710832145

Mondy, W. (2010). Human resources management (11th ed.). Prentice Hall.

Munizu, M. (2013). The impact of total quality management practices towards competitive advantage and organizational performance: case of fishery industry in South Sulawesi Province of Indonesia. Pak J Commer Soc Sci, 7(1), 184-197.

Mwaniki, C., \& Okibo, B. W. (2014). Effects of total quality management on financial performance in the banking sector: a case study of national bank of Kenya. IOSR Journal of Economics and Finance (IOSR-JEF), 3(2), 34-40. https://doi.org/10.9790/5933-03233440

Nayyab, H., Hamid, M., Naseer, F., \& Iqbal, M. (2011). The impact of HRM practices on the organizational performance. The study of banking sector in Okara, Punjab (Pakistan). Interdisciplinary Journal of Contemporary Research in Business, 3(3).

Neeraj, K. (2014). Using performance appraisal as an effective tool for motivating the employee's performance: a live study. SAGE Journal, 2(2), 37-46. https://doi.org/10.1177/ 2278533720140205

Northouse, G. (2010). Leadership: Theory and practice (5th ed.). Sage.

Obeidat, B. Y., \& Abdallah, A. B. (2014). The relationships among human resource management practices, organizational commitment, and knowledge management processes: A structural equation modeling approach. International Journal of Business and Management, 9(3), 9. https://doi.org/10.5539/ijbm.v9n3p9

Obeidat, B., El-Rimawi, S., Maqableh, M., \& Al-Jarrah, I. (2013). Evaluating the profitability of the Islamic banks in Jordan. European Journal of Economics, Finance and Administrative Sciences, 56, 27-36.

Obeidat, B., Tarhini, A., \& Aqqad, N. (2017). The impact of intellectual capital on innovation via the mediating role of knowledge management: a structural equation modeling approach. International Journal of Knowledge Management Studies, 8(3/4), 273-298. https://doi.org/ 10.1504/IJKMS.2017.087071

Obeidat, D., Yousef, B., Tawalbeh, H. F., \& Masa'deh, R. E. (2018). The Relationship between Human Resource Management (HRM) Practices, Total Quality Management (TQM) Practices and Competitive Advantages. Modern Applied Science, 12(11). https://doi.org/ 10.5539/mas.v12n11p17

Obeidat, O., El-Rimawi, S., \& Maqableh, M. A.-J. (2013). Evaluating the profitability of the Islamic banks in Jordan. Finance and Administrative Sciences, 7(4), 18-29.

Obeidat, O., El-Rimawi, S., \& Maqableh, M. A.-J. (2013). Evaluating the profitability of the Islamic banks in Jordan. European Journal of Economics, Finance and Administrative Sciences. 
Obeidat, O., Sweis, R., Zyod, D., \& Alshurideh, M. (2012). The effect of perceived service quality on customer loyalty in internet service providers in Jordan. Journal of Management Research, 4(4), 224-242. https://doi.org/10.5296/jmr.v4i4.2130

Obeidat, O., Tarhini, A., \& Aqqad, N. (2019). The relationship among emotional intelligence, conflict management styles, and job performance in Jordanian banks. International Journal of Human Resources Development and Management, Forthcoming.

Ooi, B., Lin, B., Tan, I., \& Chong, L. (2011). Are TQM practices supporting customer satisfaction and service quality? Journal of Services Marketing, 25(6), 410-419. https://doi.org/10.1108/08876041111161005

Osibanjo, O., Adeniji, A. F., \& Heirsmac, P. (2014). Compensation packages: a strategic tool for employees' performance and retention. Leonardo Journal of Sciences, 25, 65-84.

Osman, I., Ho, T. C., \& Galang, M. C. (2011). The relationship between human resource practices and firm performance: an empirical assessment of firms in Malaysia. Business Strategy Series. https://doi.org/10.1108/17515631111100412

Othman, Y. (2016). Total Quality Management As A Strategic Option for Achieving Competitive Advantage in Architectural Design Firms.

Pankaj, M. (2012). Implementing a functional ISO 9000 quality management system in MSMES. Indian Journal of Management Science, 1, 16-23.

Pao-Long, C., \& Wei-Ling, C. (2002). The effect of human resource management practices on firm performance: Empirical evidence from high-tech firms in Taiwan. International Journal of Management, 19(4).

Pearce, J. A., \& Robinson, R. B. (2007). Strategic Management: Strategy Formulation and Implementation. Irwin Inc.

Peng, W. (2009). Global Strategic Management (2nd ed.). Cengage Learning.

Phin, L. (2015). The effectiveness of performance appraisal in the private education industry of Malaysia. International Journal of Business \& Information, 10(1), 95-31.

Porter, M. E. (1998). Clusters and the new economics of competition (Vol. 76(6)). Boston.

Qi, J., Zhou, Y., Chen, W., \& Qu, Q. (2012). Are customer satisfaction and customer loyalty drivers of customer lifetime value in mobile data services: a comparative cross-country study. InfTechnol Management, Information Technology and Management, 13(4). https://doi.org/ 10.1007/s10799-012-0132-y

Rahman, S. (2011). Differentiation of services to achieve competitive advantage: airlines meeting the needs of the physically challenged persons.

Reed, R. L., \& Mero, N. (2000). Total quality management and sustainable competitive advantage. Journal of Quality Management, 5, 26-31. https://doi.org/10.1016/S1084-8568 (00)00010-9

Rondeau, K. V., \& Wagar, T. H. (2001). Impact of human resource management practices on nursing home performance. Health Services Management Research, 14(3). https://doi.org/ $10.1177 / 095148480101400306$

Sălăgean, H. (2014). Implementation of quality management-the importance of leadership styles. Managerial Challenges of the Contemporary Society, 7(1). 
Saleh, M. (2015). Customer satisfaction and brand switching intention: a study of mobile services in Saudi Arabia. Expert Journal of Marketing, 3(2), 62-72.

Sanchez-Marin, G., \& Baixauli-Soler, J. S. (2015). TMT pay dispersion and firm performance: the moderating role of organizational governance effectiveness. Journal of Management \& Organization, 21(4), 436-459. https://doi.org/10.1017/jmo.2014.87

Shafeek, H. (2014). Continuous improvement of maintenance process for the cement industry-a case study. Journal of Quality in Maintenance Engineering, 20(4), 333-376. https://doi.org/10.1108/JQME-07-2013-0047

Shannak, R., \& Obeidat, B. (2012). Culture and the implementation process of strategic decisions in Jordan. Journal of Management Research, 4(4), 257-281. https://doi.org/10. 5296/jmr.v4i4.2160

Sharma, M., \& Jain, S. (2019). Leadership management: principles, models and theories. Global Journal of Management and Business Studies, 3(3), 309-318.

Shrout, P. E., \& Bolger, N. (2002). Mediation in Experimental and Nonexperimental Studies: New Procedures and Recommendations. The American Psychological Association, Inc. https://doi.org/10.1037/1082-989X.7.4.422

Singh, D. (2014). Employee survey on performance appraisal system (a case study of BHEL: HERP Varanasi). Indian Journal of Applied Research, 4(6), 83-85. https://doi.org/10.15373/ 2249555X/June2014/25

Singh, J., \& Singh, H. (2014). Role of CI enablers for improving the performance of manufacturing industry of northern India. International Journal Productivity and Quality Management, 14(2), 179-195. https://doi.org/10.1504/IJPQM.2014.064475

Singh, K. (2003). The effect of human resources practices on firm performance in India. Human Resource Development International, 6(1). https://doi.org/10.1080/13678860110 070200

Stringham, S. H. (2004). Does quality management work in the public sector. Public Administration and Management: An Interactive Journal, 9(3).

Suklev, B., \& Debarliev, S. (2015). Strategic planning effectiveness comparative analysis of the Macedonian context. Economic and Business Review, 14(1), 63-93.

Tabassum, A. (2011). The process of recruitment and selection in a developing country:. ABAC Journal, 31(1), 55-67.

Takeuchi, N., \& Wakabayashi, Z. (2003). The strategic HRM configuration for competitive advantage: evidence from Japanese firms in china and Taiwan. Asia Pacific Journal of Management, 20(4), 447-480. https://doi.org/10.1023/A:1026386925473

Tamer, K., \& Darwish. (2009). The impact of strategic human resource management implementation on firm. BBS Doctoral Symposium 23rd \&24th March 2009.

Tarhini, A., Al-Badi, A., Almajali, M., \& Alrabayaah, S. (2017a). Factors influencing employees' intention to use cloud computing. Journal of Management and Strategy, 8(2), 47. https://doi.org/10.5430/jms.v8n2p47

Tarhini, A., Al-Busaidi, K., Bany Mohammed, A., \& Maqableh, M. (2017b). Factors influencing students' adoption of e-learning: a structural equation modeling approach. 
Journal of International Education in Business, 10(2), 164-182. https://doi.org/10.1108/ JIEB-09-2016-0032

Teh, L. (2010). Role conflict as mediator of the relationship between total quality management practices and role ambiguity. Unpublished master thesis, Malaysia.

Terpstra, D. E., \& Rozell, E. J. (1993). The relationship of staffing practices to organizational level measures of performance. Personnel Psychology, 46(1). https://doi.org/10.1111/j.17446570.1993.tb00866.x

Thompson, A., Petraf, M., Gamble, J., \& Strickland, J. (2010). Crafting and Executing Strategy (15 ed.). Mc Graw Hill .

Todeva, E., \& John, R. (2001). Shaping the competition and building competitive advantage in the global. Eam 9th International Conference 17-21 June 2001. Costa Rica.

Torrington, D., Hall, L., \& Taylor, S. (2005). Ethics and corporate social responsibility.Human Resource Management (6th ed.).

Tzafrir, S. S. (2006). A universalistic perspective for explaining the relationship between HRM practices and firm performance at different points in time. Journal of Managerial Psychology. https://doi.org/10.1108/02683940610650730

Usrof, H. J., \& Elmorsey, R. M. (2016). Relationship between HRM and TQM and its Influence on Organizational Sustainability. International Journal of Academic Research in Accounting, Finance and Management Sciences, 6(2), 21-33. https://doi.org/10.6007/IJAR AFMS/v6-i2/2036

Van Vianen, A. E., Pater, I. E., \&\& Dijk, F. V. (2007). Work value fit and turnover intention: same-source or different-source fit. Journal of managerial psychology, 22(2), 188-202. https://doi.org/10.1108/02683940710726438

Vel, P., Creed, B., \& Narayan, S. (2012). The corporate strategy of Dubai Duty Free. Asian Journal of Business and Management Sciences, 40-52, 40-52.

Velmurugan, S., \& Akhilesh, K. B. (2019). Sustained competitive advantage: strategic HRM initiatives and consequences in Indian context. International Journal of Social, Behavioral, Educational, Economic, Business and Industrial Engineering, 7(8).

Volberda, H. (2010). Strategic Management: Competitiveness and Globalization (Concepts and Cases). Andover: Cengage Learning EMEA.

Waiganjo, E., Mukulu, E., \& Kahiri, J. (2012). The relationship between strategic human resource management and firm performance of Kenya's corporate organizations. International Journal of Humanities and Social Science, 2(10).

Wen-Cheng, W., Chien-Hung, L., \& Ying-Chien, C. (2011). Types of competitive advantage and analysis. International Journal of Business and Management, 6(5), 100-104. https://doi.org/10.5539/ijbm.v6n5p100

Yang, C. C. (2006). The impact of human resource management practices on the implementation of total quality management. The TQM magazine, 18(2), 162-173. https://doi.org/10.1108/09544780610647874

Yeganeh, H., \& Su, Z. (2008). An examination of human resource management practices in Iranian public sector. Personnel Review. https://doi.org/10.1108/00483480810850542 


\section{Copyright Disclaimer}

Copyright for this article is retained by the author(s), with first publication rights granted to the journal.

This is an open-access article distributed under the terms and conditions of the Creative Commons Attribution license (http://creativecommons.org/licenses/by/3.0/). 